\title{
Reconstruction of the biogeochemistry and ecology of photoautotrophs based on the nitrogen and carbon isotopic compositions of vanadyl porphyrins from Miocene siliceous sediments
}

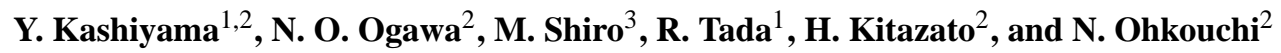 \\ ${ }^{1}$ Department of Earth and Planetary Science, University of Tokyo, Tokyo, Japan \\ ${ }^{2}$ Institute for Research on Earth Evolution, Japan Agency for Marine-Earth Science and Technology, Yokosuka, Japan \\ ${ }^{3}$ X-ray Research Laboratory, Rigaku Co., Akishima, Japan
}

Received: 29 November 2007 - Published in Biogeosciences Discuss.: 30 January 2008

Revised: 24 April 2008 - Accepted: 30 April 2008 - Published: 15 May 2008

\begin{abstract}
We determined both the nitrogen and carbon isotopic compositions of various vanadyl alkylporphyrins isolated from siliceous marine sediments of the Onnagawa Formation (middle Miocene, northeastern Japan) to investigate the biogeochemistry and ecology of photoautotrophs living in the paleo-ocean. The distinctive isotopic signals support the interpretations of previous works that the origin of 17-nor-deoxophylloerythroetioporphyrin (DPEP) is chlorophylls- $c_{1-3}$, whereas 8-nor-DPEP may have originated from chlorophylls- $a_{2}$ or $b_{2}$ or bacteriochlorophylla. Although DPEP and cycloheptanoDPEP are presumably derived from common precursory pigments, their isotopic compositions differed in the present study, suggesting that the latter represents a specific population within the photoautotrophic community. The average $\delta^{15} \mathrm{~N}$ value for the entire photoautotrophic community is estimated to be -2 to $+1 \%$ o from the $\delta^{15} \mathrm{~N}$ values of DPEP ( -6.9 to $3.6 \%$; $n=7$ ), considering that the empirical isotopic relationships that the tetrapyrrole nuclei of chloropigments are depleted in ${ }^{15} \mathrm{~N}$ by $\sim 4.8 \%$ and enriched in ${ }^{13} \mathrm{C}$ by $\sim 1.8 \%$ o relative to the whole cells. This finding suggests that nitrogen utilized in the primary production was supplied mainly through $\mathrm{N}_{2}$-fixation by diazotrophic cyanobacteria. Based on the $\delta^{13} \mathrm{C}$ values of DPEP ( -17.9 to $\left.-15.6 \% ; n=7\right)$, we estimated isotopic fractionation associated with photosynthetic carbon fixation to be $8-14 \%$. This range suggests the importance of $\beta$-carboxylation and/or active transport of
\end{abstract}

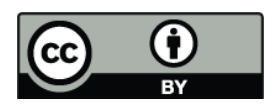

Correspondence to: Y. Kashiyama (chiro@jamstec.go.jp) the carbon substrate, indicating in turn the substantial contribution of diazotrophic cyanobacteria to primary production. Based on the $\delta^{15} \mathrm{~N}$ values of 17-nor-DPEP (-7.4 to $-2.4 \% ; n=7)$, the $\delta^{15} \mathrm{~N}$ range of chlorophylls- $c$-producing algae was estimated to be -3 to $+3 \%$. This relative depletion in ${ }^{15} \mathrm{~N}$ suggests that these algae mainly utilized nitrogen regenerated from diazotrophic cyanobacteria. Given that diatoms are likely to have constituted the chlorophylls- $c$ producing algae within the biogenic-silica-rich Onnagawa Formation, cyanobacteria-hosting diatoms may have been important contributors to primary production.

\section{Introduction}

Sedimentary porphyrins offer great potential in terms of tracing biogeochemical processes related to past photoautotrophic activity. These compounds are mainly derived from chloropigments (chlorophylls and bacteriochlorophylls), with minor amounts originating from heme. Sedimentary porphyrins are well preserved in organic-rich sediments, oil shales, and petroleum (e.g., Treibs, 1936; Baker and Louda, 1986; Callot and Ocampo, 2000). Because the structural characteristics of porphyrins reflect those of the source chloropigments, significant efforts have been made to assess the structure of porphyrins isolated from sediments with the aim of understanding their precursors and diagenetic transformation (Baker and Palmer, 1978; Ocampo et al., 1985, 1992; Baker and Louda, 1986; Keely et al., 1988, 1990, 1994; Verne-Mismer et al., 1988; Boreham et al., 1990; Prowse et al., 1990; Eckardt et al., 1991; Keely and

Published by Copernicus Publications on behalf of the European Geosciences Union. 
Maxwell, 1991; Sundararaman and Boreham, 1991; Gibbison et al., 1995; Callot and Ocampo, 2000). The stable isotopic compositions of nitrogen and carbon in porphyrins also provide critical information on their source organisms (Hayes et al., 1987; Boreham et al., 1989, 1990; Ocampo et al., 1989; Popp et al., 1989; Chicarelli et al., 1993; Keely et al., 1994; Ohkouchi et al., 2006).

Sedimentary porphyrins preserved in marine sediments originate only from the chloropigments of aquatic photoautotrophs, thereby exclusively recording the signal from the marine primary production. The contribution of chlorophylls from the terrestrial environment to marine sediments is expected to be negligibly small for the following reasons. First, the chlorophylls of higher plants, potentially major chlorophyll producers on land, are enzymatically decomposed during senescence of the leaf (Kräutler et al., 1991; Matile et al., 1996; Oberhuber et al., 2003). Second, chlorophylls and their derivatives are rapidly decomposed by bacteria in soils (Hoyt, 1966) or grazed by mesofauna (Chamberlain et al., 2006). Finally, chlorophylls are readily oxidized under aerobic conditions and/or photo-degraded during transport (Sanger, 1988). In fact, Chikaraishi et al. (2005b) reported that chlorophylls and their degradation products originating from terrestrial plants were present in only minor amounts in a small lake with a high flux of organic matter from the surrounding forest.

The nitrogen and carbon isotopic compositions of sedimentary porphyrins from marine sediments should therefore reflect those of photoautotrophs in the environment at the time of deposition, thereby providing crucial information on the physiology and ecology of the phototrophic community and the physicochemical conditions of the surface ocean (Hayes et al., 1987; Boreham et al., 1989, 1990; Ocampo et al., 1989; Popp et al., 1989; Chicarelli et al., 1993; Keely et al., 1994; Ohkouchi et al., 2006). Such information is otherwise difficult to extract based on sedimentological and other geochemical proxies. The isotopic compositions of sedimentary porphyrins are expected to preserve the compositions of the tetrapyrrole nuclei of chlorophylls even after diagenetic modification (Sachs et al., 1999; Ohkouchi et al., 2006, 2008). For this reason, relatively constant isotopic relationships are theoretically predicted between the photoautotrophic biomass and sedimentary porphyrins, because the tetrapyrrole nuclei of chlorophylls are synthesized via a unique biosynthetic pathway after the condensation of eight 5-aminolevulinic acid (ALA; Beale, 1995). Empirically, porphyrins are depleted in ${ }^{15} \mathrm{~N}$ by $4.8 \pm 1.4 \%$ o $(1 \sigma, n=20)$ and enriched in ${ }^{13} \mathrm{C}$ by $1.8 \pm 0.8 \%$ o $(1 \sigma, n=18)$ relative to cell biomass (Ohkouchi et al., 2006; 2008).

The nitrogen isotopic composition of photoautotrophs is of particular interest because it provides information about nitrogen processes in the surface ocean (Chicarelil et al., 1993; Ohkouchi et al., 2006). For example, the nitrogen isotopic composition of photoautotrophs typically ranges from +5 to $+7 \%$ in most oceanic environments, reflecting the presence of ${ }^{15} \mathrm{~N}$-enriched nitrate in oceanic water (Miyake and Wada, 1967; Cline and Kaplan, 1975; Liu and Kaplan, 1989; Brandes et al., 1998; Voss et al., 2001; Sigman et al., 2005); however, once the nitrate becomes consumed and is significantly depleted, dissolved $\mathrm{N}_{2}$ is made biologically available via the fixation of $\mathrm{N}_{2}$ by diazotrophs (i.e., $\mathrm{N}_{2}$-fixing organisms), a process that catalytically converts dinitrogen to ammonium with only minor isotopic fractionation $(\alpha=1.000$ 1.002; Hoering and Ford, 1960; Delwiche and Steyn, 1970; Wada, 1980; Wada and Hattori, 1991). Consequently, the $\delta^{15} \mathrm{~N}$ values for diazotrophs fall within a confined, characteristic range from -3 to 0\%o (e.g., Minagawa and Wada, 1986; Montoya et al., 2002). Finally, in a reduced, anaerobic environment, photoautotrophs are significantly depleted in ${ }^{15} \mathrm{~N}$ because of the large amount of isotopic fractionation that accompanies the uptake of dissolved ammonia (8-27\%o; $\mathrm{Ci}$ fuentes et al., 1989; Hoch et al., 1992; Pennock et al., 1996; Waser et al., 1998a, b).

The carbon isotopic composition of photoautotrophs reflects isotopic fractionation during the enzymatic carboxylation process $\left(\varepsilon_{f}\right)$, as well as the kinetic isotope effect during carbon mass transport into the cell (Farquhar et al., 1982b). The overall isotopic fractionation, $\varepsilon_{p}$ (defined as $10^{3}\left[\left(\delta^{13} \mathrm{C}_{\text {cell }}+1000\right) /\left(\delta^{13} \mathrm{C}_{\mathrm{CO}_{2} \mathrm{aq}}+1000\right)\right.$ $\left.1] \approx \delta^{13} \mathrm{C}_{\text {cell }}-\delta^{13} \mathrm{C}_{\mathrm{CO}_{2} \text { aq }}(\% o)\right)$, is the sum of these two effects, normally varying between -20 and $-14 \%$ in the modern ocean (Bidigare et al., 1997, 1999). Based on the assumption that ribulose 1,5-bisphosphate carboxylase/oxygenase (RUBISCO) is the sole carboxylation enzyme among algae $\left(\varepsilon_{f} \approx\right.$ $-29 \%$; Farquhar et al., 1982a; Guy et al., 1987), $\varepsilon_{p}$ values have been used as a proxy for past atmospheric $P_{\mathrm{CO}_{2}}$, which is presumably the primary factor governing the kinetic isotopic effect (Popp et al., 1989; Jasper and Hayes, 1990; Freeman and Hayes, 1992; Jasper et al., 1994; Pagani et al., 1999). Nonetheless, it is also possible that $\varepsilon_{p}$ values indicate changes in the photoautotrophic community in terms of their physiology, because the isotopic effects of the active transport of substrates or alternative carboxylation enzymes are expected to dominate over the influence of $P_{\mathrm{CO}_{2}}$ (Raven, 1997; Kashiyama et al., 2008).

We recently developed an improved method for the isolation and purification of sedimentary metalloalkylporphyrins using high-performance liquid chromatography (Kashiyama et al., 2007a; Kashiyama et al., 2008), specifically designed for compound-specific isotopic analyses. In the present work, we applied this method to determine both the nitrogen and carbon isotopic compositions of various vanadyl alkylporphyrins isolated from siliceous sediments of the middle Miocene Onnagawa Formation, northeastern Japan. Based on these data, we discuss the source-product relationships of various sedimentary porphyrins and the biogeochemistry and ecology of photoautotrophs in a marginal basin of the Miocene Pacific Ocean. 


\section{Samples and experimental}

\subsection{Samples and geological background}

The middle Miocene Onnagawa Formation consists of hemipelagic siliceous sediments, making up part of a thick Neogene sequence deposited in the Tohoku Trough, a narrow, NNE-SSW-trending failed rift basin located on the eastern margin of the Japan Sea (Fig. 1). The Onnagawa Formation and its equivalents in adjacent areas consist of fine-grained, diatomaceous deposits that are underlain by shallow marine facies deposited during the opening of the basin and overlain by siliciclastic facies deposited during aggradation within the basin. The opening of the Tohoku Trough was initiated at $\sim 17.5 \mathrm{Ma}$, and it rapidly deepened to $1500 \mathrm{~m}$ by $15 \mathrm{Ma}$ when deposition of the Onnagawa Formation began (Iijima and Tada, 1990). During deposition of the Onnagawa Formation, the basin was semi-enclosed and estimated to have been connected to the Pacific Ocean via a sill of 150-500 m depth located to the north of the basin (Iijima and Tada, 1990). Studies on lipid biomarkers from the Onnagawa Formation and their carbon isotopic compositions have been conducted by Suzuki et al. (1993), Yamamoto and Watanabe (1994), Sampei et al. (2003), and Yamamoto et al. (2005).

The studied section is located in the Gojome area, Akita Prefecture, Japan (Fig. 1). The Onnagawa Formation in this area generally exhibits centimeter- to decimeter-scale rhythmical alternations of dark-colored argillaceous layers that are relatively enriched in pyrite and organic matter, and lightcolored biogenic silica-rich layers. These laminations reflect variations in the flux of diatomaceous silica at a periodicity of hundreds to thousands of years (Tada, 1991; Koshikawa, 2002). Moreover, laminations at the scale of hundreds of microns are commonly preserved throughout the section, suggesting the repeated development of anaerobic environments in the bottom-water. The formation is also characterized by elevated TOC contents of up to $5 \%$ (Tada, 1991).

The lithology and stratigraphy of the studied section have been described in detail in previous studies (Fig. 1; Tada, 1991; Koshikawa, 2002). Seven samples that represent various lithofacies (BA138b; BA140a-III, IV, and V; and GJ01-3, 7, and G) were obtained from two distinct stratigraphic levels (Horizons 1 and 2; Fig. 1) and analyzed for both bulk organic matter and sedimentary porphyrins (Table 1 ).

\subsection{Experimental procedures}

\subsubsection{Isolation of individual porphyrins}

Sedimentary porphyrins were extracted from approximately $0.5 \mathrm{~kg}$ of pulverized sediments of each sapmle by Soxhlet extraction with chloroform/methanol $(70: 30, \mathrm{v} / \mathrm{v})$ for $\sim 72 \mathrm{~h}$. We conducted isolation and purification of individual vanadyl alkylporphyrins by applying the method described in Kashiyama et al. (2007a), which were then ana- lyzed isotopically and/or structurally. An updated high performance liquid chromatography (HPLC) method was employed for sample BA138b. To avoid the artifact caused by chromatographic isotopic fractionation during isolation in the HPLC method (Macko et al., 1987; Bidigare et al., 1991; Hare et al., 1991; Filer, 1999), Kashiyama et al. (2007a) introduced a dual-step HPLC method to separate individual compounds with baseline resolution (described below; Fig. 2a and b). Furthermore, because 3-nordeoxophylloerythroetioporphyrin (DPEP) (1c) and 8-norDPEP (1d) were not resolved in the second-step normalphase HPLC, the isolated fraction containing these two compounds was further separated by reversed-phase HPLC with extended column length in order to separate with baseline resolution for isolation (described below; Fig. 2c)

The HPLC methods described below are an update of those provided by Kashiyama et al. (2007a) after the introduction of a temperature-controlled column oven; they were used for the preparation of sample BA138b. The methods used for the rest of the samples are described in detail in Kashiyama et al. (2007a). The HPLC system (Agilent 1100 series) comprised a binary pump, on-line degasser, autosampler, HPLC column oven (Selerity Technologies Inc.; POLARATHERM $^{\mathrm{TM}}$ Series 9000), and on-line photodiode array detector (DAD), and was optionally equipped with a fraction collector and a mass selective detector (MSD) connected via an atmospheric pressure chemical ionization (APCI) interface. The system was coupled to a personal computer installed with Agilent Chemstation software.

In the reversed-phase HPLC, analyses were performed using three analytical-scale columns (ZORBAX SB-C18, $4.6 \times 250 \mathrm{~mm} ; 5 \mu \mathrm{m}$ silica particle size) connected in series with a guard column (ZORBAX SB-C18, $4.6 \times 12.5 \mathrm{~mm}$; $5 \mu \mathrm{m}$ silica particle size) set in front. The isocratic mobile phases were acetonitrile/water/acetic acid/pyridine (90:10:0.5:0.5, v/v) for the high-resolution HPLC analysis mode and acetonitrile/ $\mathrm{N}, \mathrm{N}$-dimethylformamide/water/acetic acid/pyridine (70:20:10:0.5:0.5, v/v) for the high-samplecapacity HPLC purification mode; these correspond to "Mode A" and "Mode B" of Kashiyama et al. (2007a), respectively. The temperature program for the column oven and flow rate are summarized in Table $2 \mathrm{a}$ and $b$. In the normal-phase HPLC, analyses were performed using five analytical-scale columns (ZORBAX Sil, $4.6 \times 250 \mathrm{~mm} ; 5 \mu \mathrm{m}$ silica particle size) connected in series with a guard column (ZORBAX Sil, $4.6 \times 12.5 \mathrm{~mm}$; $5 \mu \mathrm{m}$ silica particle size) set in front. The isocratic mobile phases were $n$-hexane/dichloromethane/N,Ndimethylformamide/acetic acid/pyridine (88:10:1:0.5:0.5, $\mathrm{v} / \mathrm{v}$ ), and the flow rate was $1 \mathrm{ml} \mathrm{min}^{-1}$. The temperature program for the column oven in normal-phase HPLC is summarized in Table 2c.

We undertook additional reversed-phase HPLC for the isolation of 3-nor- and 8-nor-DPEP (1c and 1e). Seven analytical-scale columns (ZORBAX SB-C18, 4.6×250 mm; 

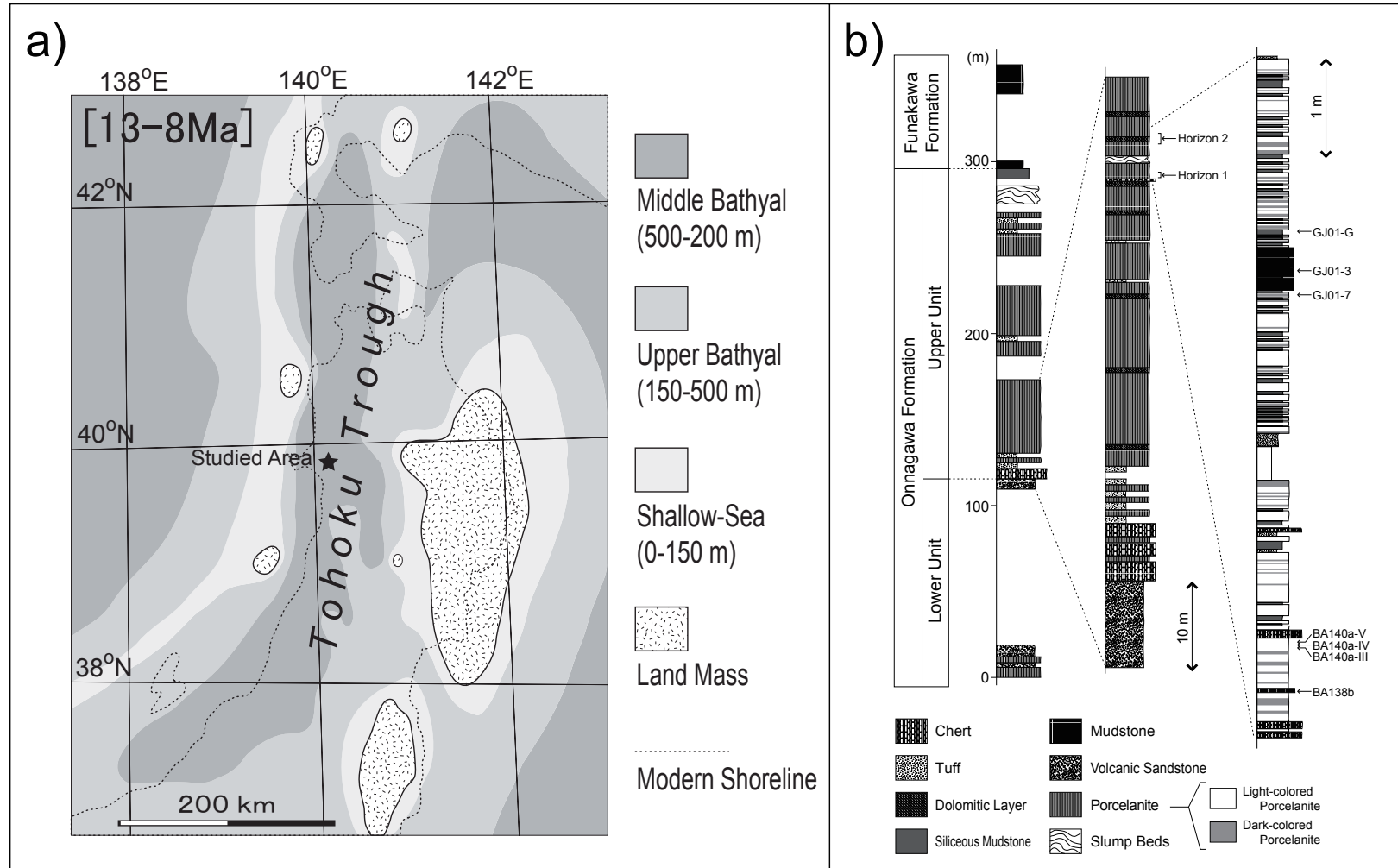

Fig. 1. (a) Paleogeographic map and (b) stratigraphic column for the middle Miocene sequence exposed in the Gojome area of northeast Japan. Horizons 1 and 2 represent the stratigraphic intervals sampled in the present study.

Table 1. Description and bulk properties of the samples analyzed for porphyrin isotopic compositions.

\begin{tabular}{|c|c|c|c|c|c|c|c|c|c|}
\hline \multicolumn{2}{|c|}{ Identification } & Description & $\begin{array}{l}\text { Sample } \\
\text { thickness } \\
(\mathrm{mm})\end{array}$ & $\begin{array}{l}\text { Biogenic } \\
\text { silica } \\
\text { (wt. \%)* }\end{array}$ & $\begin{array}{l}\delta^{15} \mathrm{~N} \\
(\%)\end{array}$ & $\begin{array}{l}\delta^{13} \mathrm{C} \\
(\% o)\end{array}$ & $\begin{array}{l}\mathrm{TN} \\
\text { (wt. \%) }\end{array}$ & $\begin{array}{l}\text { TOC } \\
\text { (wt. \%) }\end{array}$ & $\begin{array}{l}\text { Carbonate } \\
\text { (wt. \%) }\end{array}$ \\
\hline \multicolumn{10}{|l|}{ Horizon 1} \\
\hline \multirow[t]{3}{*}{ BA138b } & & Brown dolomite & 31 & 38 & 2.7 & -22.3 & 0.04 & 1.3 & 62.6 \\
\hline & III & Light-colored & 10 & & 2.2 & -23.2 & 0.04 & 1.0 & 1.9 \\
\hline & & porcelanite & & & & & & & \\
\hline & IV & $\begin{array}{l}\text { Dark-colored } \\
\text { porcelanite }\end{array}$ & 15 & & 2.1 & -23.0 & 0.04 & 1.0 & 2.5 \\
\hline & V & $\begin{array}{l}\text { Light-colored } \\
\text { porcelanite }\end{array}$ & 15 & & 2.2 & -23.0 & 0.04 & 1.1 & 2.0 \\
\hline \multicolumn{10}{|l|}{ Horizon 2} \\
\hline \multicolumn{2}{|l|}{ GJ01-7 } & $\begin{array}{l}\text { Dark-colored } \\
\text { porcelanite }\end{array}$ & 54 & 52 & 2.4 & -22.0 & 0.08 & 1.9 & 21.6 \\
\hline \multicolumn{2}{|l|}{ GJ01-3 } & Brown dolomite & 43 & 23 & 2.3 & -22.2 & 0.12 & 3.1 & 61.4 \\
\hline \multicolumn{2}{|l|}{ GJ01-G } & $\begin{array}{l}\text { Dark siliceous } \\
\text { mudstone }\end{array}$ & 46 & 40 & 2.5 & -22.1 & 0.13 & 3.6 & 25.3 \\
\hline
\end{tabular}

* After Tada (1991) and Koshikawa (2002). For the sample BA140a III, IV, and V, only an average value of these stratigraphically adjacent layers was reported. 

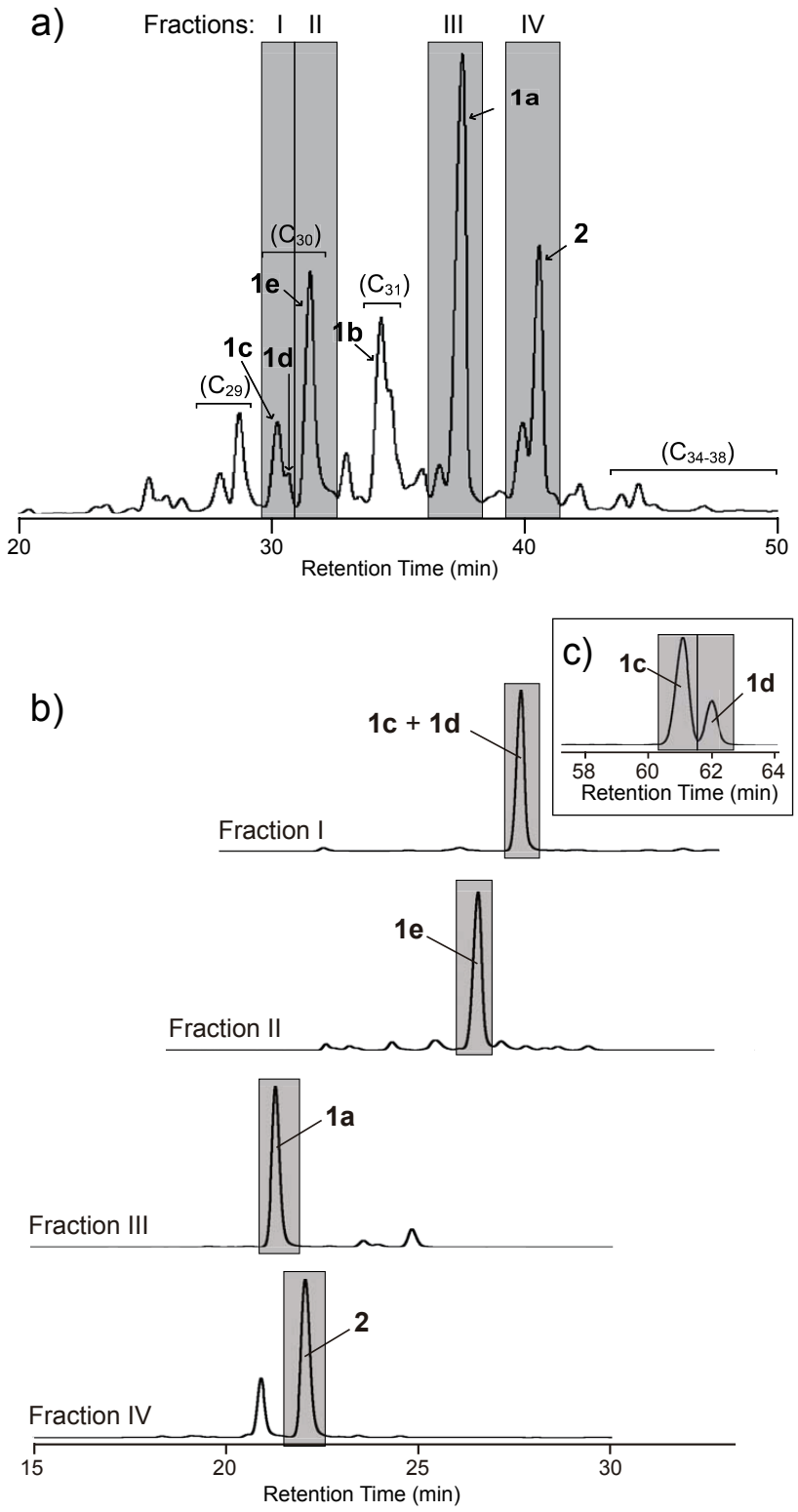

Fig. 2. (a) First-step, reversed-phase HPLC/DAD chromatogram (at $408 \mathrm{~nm}$ ) of the vanadyl alkylporphyrins fraction (sample GJ013 ). The carbon numbers of porphyrins shown here were assigned based on HPLC/MS mass spectra. Numbers in bold assigned to the major peaks refer to the chemical structure described in the Fig. A1, as conclusively determined by X-ray crystallographic analysis (see the Supplementary Material http://www.biogeosciences. net/5/797/2008/bg-5-797-2008-supplement.pdf). Shaded intervals indicate the fractions collected for second-step HPLC. (b) Secondstep, normal-phase HPLC/DAD chromatogram (at $408 \mathrm{~nm}$ ) of the fraction containing isotopically analyzed porphyrins (compounds 1a, 1c, 1d, 1e, and 2). The peaks of the target compounds were separated with baseline resolution and collected for either isotopic analyses or the third-step HPLC (shaded intervals). (c) Third-step, reversed-phase HPLC of the fraction containing compounds $1 \mathrm{c}$ and 1d.
Table 2. Gradient programs of column oven temperature and flow rate for HPLC analyses.

\begin{tabular}{lll}
\hline $\begin{array}{l}\text { a) High-resolution HPLC analysis mode } \\
\text { Time (min) }\end{array}$ & Temperature $\left({ }^{\circ} \mathrm{C}\right)$ & Flow rate $(\mathrm{ml} / \mathrm{min})$ \\
\hline 0 & 40 & 1.0 \\
10 & 40 & 1.0 \\
50 & 80 & 2.0 \\
60 & 80 & 2.0 \\
\hline b) High-sample-capacity $\operatorname{HPLC}$ purification mode \\
Time (min) & Temperature $\left({ }^{\circ} \mathrm{C}\right)$ & Flow rate $(\mathrm{ml} / \mathrm{min})$ \\
\hline 0 & 40 & 1.2 \\
40 & 80 & 1.2 \\
60 & 80 & 1.2 \\
\hline c) Normal-phase HPLC & & \\
Time (min) & Temperature $\left({ }^{\circ} \mathrm{C}\right)$ & Flow rate $(\mathrm{ml} / \mathrm{min})$ \\
\hline 0 & 35 & 1.0 \\
40 & 45 & 1.0 \\
60 & 45 & 1.0 \\
\hline
\end{tabular}

$5 \mu \mathrm{m}$ silica particle size) were connected in series with a guard column (ZORBAX SB-C18, $4.6 \times 12.5 \mathrm{~mm} ; 5 \mu \mathrm{m}$ silica particle size) set in front. The column oven temperature was set at $80^{\circ} \mathrm{C}$, the isocratic mobile phase was acetonitrile/water/acetic acid/pyridine (90:10:0.5:0.5, v/v), and the flow rate was $1 \mathrm{ml} \mathrm{min}^{-1}$.

\subsubsection{Structural identification}

The structures of porphyrins were tentatively assigned in the first instance based on HPLC/MS mass spectra, UV-Vis spectra, and comparisons of the obtained relative retention times with those published in the literature (e.g., Sundararaman and Boreham, 1993; Fig. 2). Furthermore, the structures of six isolated porphyrins (including five compounds analyzed isotopically) were determined by X-ray crystallography. Darkred crystals of isolated individual vanadyl porphyrins were grown by vapor diffusion (methanol into $\mathrm{CHCl}_{3}$ solution). Crystals were prepared from $100-800 \mu \mathrm{g}$ of each isolated compound. Single crystals with variable dimensions (as small as $0.1 \times 0.1 \times 0.02 \mathrm{~mm}$ ) were used for X-ray diffraction analyses. Measurements were made using a Rigaku RAXIS RAPID imaging plate area detector with graphite monochromated $\mathrm{Cu}-\mathrm{K} \alpha$ radiation. The crystallographic data for DPEP (1a) and 8-nor-DPEP (1d) are reported in Kashiyama et al. (2008) and Kashiyama et al. (2007b), respectively. The crystallographic data for other compounds are reported in the Supplementary Material http://www.biogeosciences.net/ 5/797/2008/bg-5-797-2008-supplement.pdf of the present study. 
Table 3. Nitrogen and carbon isotopic compositions of individual sedimentary porphyrins.

\begin{tabular}{|c|c|c|c|}
\hline & & $\delta^{15} \mathrm{~N}(\% o)$ & $\delta^{13} \mathrm{C}(\% o)$ \\
\hline \multicolumn{4}{|l|}{$B A 138 b$} \\
\hline & $1 a$ & -3.6 & -17.1 \\
\hline & $1 c$ & -3.6 & -17.0 \\
\hline & 1d & -1.4 & -21.2 \\
\hline & $1 e$ & -3.7 & -16.7 \\
\hline & 2 & -5.1 & -19.6 \\
\hline \multicolumn{4}{|c|}{ BA140a-III } \\
\hline & 1a & -5.8 & -17.8 \\
\hline & 1c & -6.7 & -17.0 \\
\hline & 1d & -1.8 & -19.7 \\
\hline & $1 e$ & -6.3 & -17.2 \\
\hline & 2 & -7.5 & -19.9 \\
\hline \multicolumn{4}{|c|}{ BA140a-IV } \\
\hline & 1a & -5.5 & -17.8 \\
\hline & $1 c$ & -5.1 & -17.9 \\
\hline & 1d & -6.5 & -22.0 \\
\hline & $1 e$ & -4.1 & -16.9 \\
\hline & 2 & -6.8 & -19.7 \\
\hline \multicolumn{4}{|c|}{$B A 140 a-V$} \\
\hline & $1 a$ & -6.9 & -17.9 \\
\hline & 1c & -6.3 & -17.4 \\
\hline & 1d & -7.2 & -20.4 \\
\hline & $1 e$ & -7.4 & -16.6 \\
\hline & 2 & -7.6 & -19.5 \\
\hline \multicolumn{4}{|l|}{ GJ01-7 } \\
\hline & 1a & -5.2 & -15.6 \\
\hline & $1 e$ & -2.4 & -15.1 \\
\hline & 2 & -5.9 & -18.6 \\
\hline \multicolumn{4}{|l|}{ GJ01-3 } \\
\hline & 1a & -4.1 & -15.6 \\
\hline & $1 e$ & -4.2 & -15.4 \\
\hline & 2 & -5.0 & -18.3 \\
\hline \multicolumn{4}{|l|}{$G J 01-G$} \\
\hline & $1 a$ & -5.4 & -15.8 \\
\hline & 1c & -5.8 & -15.8 \\
\hline & 1d & -2.3 & -17.4 \\
\hline & $1 e$ & -6.1 & -15.3 \\
\hline & 2 & -5.2 & -18.3 \\
\hline
\end{tabular}

\subsubsection{Isotopic analyses}

Nitrogen and carbon isotopic compositions were determined using a ThermoFinnigan Delta plus XP isotope-ratio mass spectrometer coupled to a Flash EA1112 automatic elemental analyzer via a Conflo III interface (EA/IRMS; Ohkouchi et al., 2005). Nitrogen and carbon isotopic compositions are expressed using conventional $\delta$-notation against atmospheric $\mathrm{N}_{2}$ (AIR) and the Peedee Belemnite (PDB), respectively. In practice, referencing was performed via comparisons with laboratory standard compounds of known isotopic compositions; namely, tyrosine $\left(\delta^{15} \mathrm{~N}=+8.44 \% o, \delta^{13} \mathrm{C}=-20.50 \%\right.$ o $)$ and $\mathrm{Ni}$ etioporphyrin $\mathrm{I}\left(\delta^{15} \mathrm{~N}=+0.86 \%\right.$ o, $\delta^{13} \mathrm{C}=-34.17 \%$ o $)$ purchased from Aldrich Chemical Co. (Milwaukee, WI, USA).
In the present work, we define isotopic fractionation between the substrate and product $(\varepsilon)$ as follows:

$$
\begin{aligned}
& \varepsilon(\% o) \equiv 10^{3}\left[\left(\delta_{\text {substrate }}+1000\right) /\left(\delta_{\text {product }}+1000\right)-1\right] \\
& \quad \approx \delta_{\text {substrate }}-\delta_{\text {product }}
\end{aligned}
$$

The purified individual metalloalkylporphyrins and the $\mathrm{Ni}$ etioporphyrin I standard were dissolved in chloroform and placed onto precleaned tin capsules. After chloroform was evaporated, the capsules were carefully folded with forceps prior to analysis. Various quantities $(6-30 \mu \mathrm{g})$ of the Ni etioporphyrin I standard were prepared over a range that covers the quantities of all of the analyzed porphyrin samples; the standard was then analyzed interspersed with the samples. The estimated analytical precisions $(1 \sigma)$ of the isotopic compositions were $0.11-0.30 \%$ o for nitrogen and $0.12-0.30 \%$ o for carbon (ranges indicate variations on different days of analysis), reflecting the instrumental condition of the EA/IRMS system. We also assessed analytical errors related to the separation and purification procedures by the repeated preparation of three major porphyrins (1a, 1e, and $\mathbf{2})$ from triplicate samples (BA138b). The average isotopic variances of these porphyrins among the three independent experiments were $0.29 \%$ o for nitrogen and $0.11 \%$ o for carbon $(1 \sigma)$. Overall, the inclusive analytical errors for all analyses presented in this paper were $0.3 \%$ o for both nitrogen and carbon.

\section{Results}

The Onnagawa Formation contains nickel, copper, and vanadyl alkylporphyrins, with the latter being by far the most abundant (approximately $40 \mathrm{nmol} \mathrm{g}^{-1}$-sediment; Kashiyama, 2006); accordingly, the present study focused on the vanadyl alkylporphyrins.

Figure 2a shows a representative chromatogram of reversed-phase HPLC for the vanadyl porphyrin fraction. The major constituents of the vanadyl porphyrins do not differ among the seven analyzed samples, although they vary in their relative amounts (Fig. 3). DPEP (1a) was the most abundant porphyrin in all samples (15-30\% of total vanadyl porphyrins), with either 17-nor-DPEP (1e) or $\mathrm{C}_{33}$ cycloheptanoDPEP (2) being the second-most abundant. Other major components included 3-methyl-DPEP (1b), 3-nor- DPEP (1c), and $\mathrm{C}_{29}$ cycloalkanoporphyrin (structure tentatively assigned).

The nitrogen and carbon isotopic compositions of individual porphyrins from the seven samples are summarized in Table 3. Overall, the examined porphyrins show wide ranges in isotopic compositions, from -8 to $-2 \%$ o for nitrogen and from -19 to $-15 \%$ o for carbon. Certain isotopic trends are observed among various porphyrins from each sample (Fig. 4), probably reflecting physiological variations among distinctive source photoautotrophs. Below, we examine the relative isotopic differences among different porphyrin species 
and their chemical structures with the aim of elucidating the source-product relationships between the studied sedimentary porphyrins and their precursory chloropigments.

\section{Discussion}

\subsection{Source-product relationships of various porphyrins}

\subsubsection{Origins of 17-nor-DPEP}

17-nor- DPEP was first reported by Shul'ga et al. (1986) and Serebrennikova et al. (1987) from Siberian oil. A specific origin for this compound was suggested by VerneMismer et al. (1988), who considered it as a degradation product of chlorophylls- $c_{1-3}$ after the defunctionalization of the carboxyvinyl group at the $\mathrm{C}-17$ position via a reaction analogous to the Schumm devinylation reaction (Di Nello and Dolphin, 1981). In contrast, most varieties of chlorophylls and bacteriochlorophylls are potential sources of DPEP (1a), the most abundant sedimentary porphyrin (Fig. 3), although it is expected to be most commonly derived from chlorophyll- $a_{1}(\mathbf{6 a})$, the main photosynthetic pigment of virtually every quantitatively significant aquatic photoautotroph in an aerated biosphere. 17-nor-DPEP may also have a non-specific origin such as DPEP after the defunctionalization of the carboxyethyl group in other kinds of chloropigments or after the thermal cleavage of the C-17 ethyl group of DPEP. In the present study, we observed statistically significant ${ }^{13} \mathrm{C}$-enrichment in 17-nor-DPEP relative to that in DPEP (Fig. 4; see statistical tests in Table $\mathrm{S} 1$ in Supplementary Materials http://www.biogeosciences. net/5/797/2008/bg-5-797-2008-supplement.pdf), supporting the specific origin of 17-nor-DPEP, chlorophylls- $c$ in particular. Thus, it is plausible that the isotopic compositions of 17-nor-DPEP represent those of the marine algal groups that produce chlorophylls- $c$, including diatoms, haptophytes, and dinoflagellates.

\subsubsection{Origins of 3-nor- and 8-nor-DPEP}

In addition to 17-nor-DPEP (1e), two other varieties of $\mathrm{C}_{30}$ porphyrins lacking an ethyl group of DPEP (1a) were observed: 3-nor- and 8-nor-DPEPs (1c and 1d, respectively). Considering the biosynthetic scheme of chloropigments, ethyl groups that are lost from the C-3, C-8, or C-17 positions are equivalent in their ultimate origin because the two carbon atoms of each ethyl group originate in the two methylene carbons of the carboxyethyl group of Uroporphobilinogen (9), a universal precursor of all chlorophyllides. Therefore, losses of ethyl groups at these positions would not differentiate the carbon isotopic compositions of the three porphyrins, if derived from a common source. Given that in the present study we obtained contrasting isotopic data for the three $\mathrm{C}_{30}$ porphyrins (Fig. 4a), we conclude that they
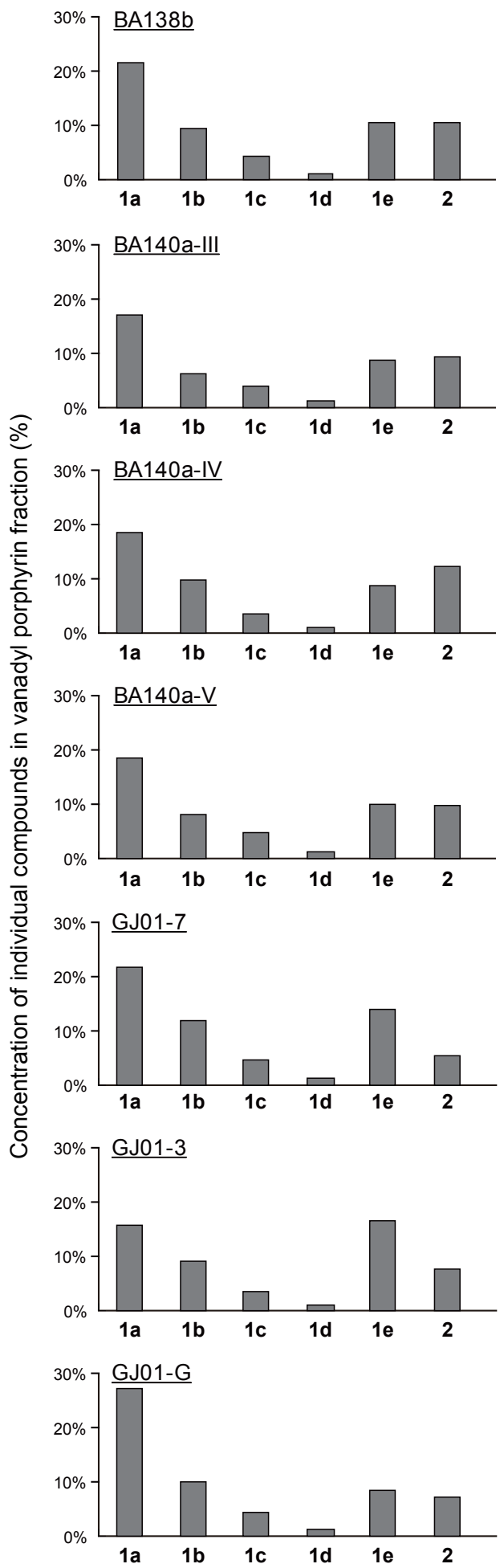

Fig. 3. Relative abundances of major components in the seven analyzed samples. Numbers in bold refer to the chemical structure described in the Fig. A1. 

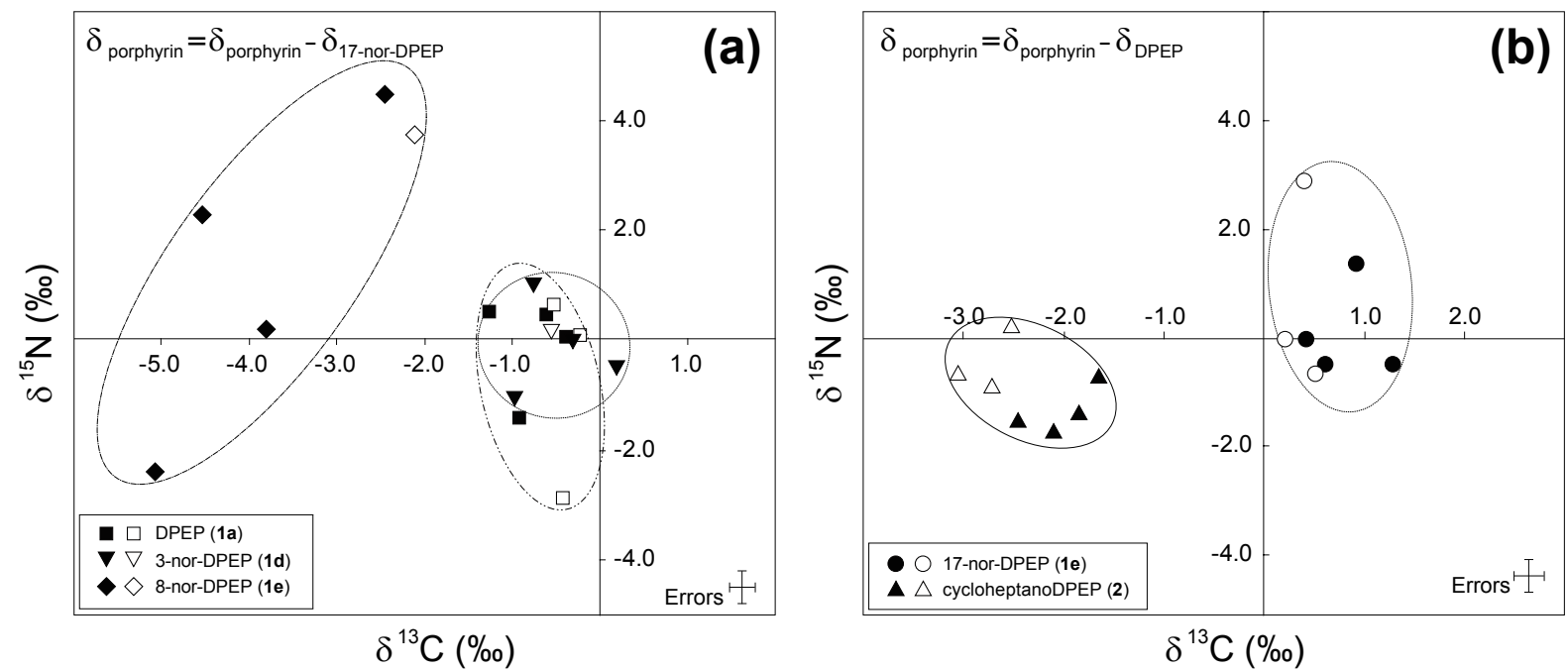

Fig. 4. Relative isotopic variations obtained for different sedimentary porphyrins from Horizon 1 (filled symbols) and Horizon 2 (open symbols). $\Delta^{15} \mathrm{~N}$ and $\Delta^{13} \mathrm{C}$ refer to isotopic differences for each porphyrin relative to (a) 17-nor-DPEP and (b) DPEP. The isotopic signatures from different horizons reflect temporal variations in environmental factors such as the $\delta^{13} \mathrm{C}$ of DIC or the $\delta^{15} \mathrm{~N}$ of upwelled nitrate. $\Delta^{15} \mathrm{~N}$ and $\Delta^{13} \mathrm{C}$ are expected to extract signatures solely attributed to variations in physiology within the photoautotrophic community by cancelling environmental factors, assuming that the isotopic signature of DPEP represents that of the entire community.

were derived from chloropigments with different biological sources.

3-nor-DPEP (1c) tends to be slightly depleted in ${ }^{13} \mathrm{C}$ relative to 17 -nor-DPEP $\left(\mathbf{1 e} ; \quad \Delta{ }^{13} \mathrm{C}=-0.5 \pm 0.4 \%\right.$; $1 \sigma ; n=5 ;$ see statistical tests in Table $\mathrm{S} 1$ in Supplementary Materials http://www.biogeosciences.net/5/797/ 2008/bg-5-797-2008-supplement.pdf), but is isotopically indistinguishable from DPEP $\left(\mathbf{1 a} ; \Delta^{15} \mathrm{~N}=-0.1 \pm 0.6 \%\right.$; $\Delta{ }^{13} \mathrm{C}=+0.3 \pm 0.4 \%$; $1 \sigma ; n=5$; Fig. $4 \mathrm{a}$; Table $\mathrm{S} 1$ in Supplementary Materials http://www.biogeosciences.net/5/797/ 2008/bg-5-797-2008-supplement.pdf). 3-nor-DPEP has been identified in many geological samples (Fookes, 1983; Sundararaman and Boreham, 1991, 1993; Sundararaman et al., 1994). Loss of the ethyl group at the C-3 position has been attributed either to Schumm-reaction-like devinylation under acidic conditions (Di Nello and Dolphin, 1981; Sundararaman and Boreham, 1991) or cleaving of the C3-C3 ${ }^{1}$ bond after the formation of a Diels-Alder adduct of the vinyl-substituted pyrrole units of two chlorophyllides (Kozono et al., 2002). Therefore, the origins of 3-nor-DPEP and DPEP are probably identical and are differentiated because of the variable fates of the vinyl group at the C-3 position (Sundararaman and Boreham, 1991; Chicarelli et al., 1993), thereby supporting the above reasoning based on structure. Alternatively, chlorophyll- $d$ (6e) could also be a precursor of 3-nor-DPEP because the formyl group at the $\mathrm{C}-3$ position of chlorophyll- $d$ can be lost by oxidation followed by decarboxylation. Chlorophyll- $d$ is a major pigment of Acaryochloris marina, a cyanobacterium that has been reported in association with reef organisms and red macroalgae (Miyashita et al., 1996, 2003; Kühl et al., 2005; Miller et al., 2005); however, the contribution of chlorophyll- $d$-producing cyanobacteria to pelagic primary production is probably only minor.

8-nor-DPEP (1d), first reported in our samples (Kashiyama et al., 2007b), shows unique and widely variable isotopic compositions (Fig. 4a); namely, $\Delta^{15} \mathrm{~N}$ and $\Delta{ }^{13} \mathrm{C}$ values relative to 17 -nor DPEP $(\mathbf{1 e})$ are $+1.7 \pm 2.8 \%$ o and $-3.6 \pm 1.3 \%$, respectively $(1 \sigma ; n=5)$. Only limited types of chloropigments readily lose the substituent at the C-8 position under a mild thermal condition; devinylation at the C-8 position of chlorophylls- $c_{2}$ and $c_{3}$ (7b and $7 \mathbf{c}$, respectively) is one possibility. Considering the significant deviation in both the nitrogen and carbon isotopic compositions of 8-nor-DPEP from those of DPEP and 17-nor-DPEP, however, 8-nor-DPEP probably originated from a unique group(s) of photoautotrophs. The devinylation at the C-8 position of chlorophylls- $a_{2}(\mathbf{6} \mathbf{b})$ and $b_{2}(\mathbf{6 d})$ may better explain the unique isotopic signatures, because these pigments are known to be produced only by a unique group of cyanobacterium, Prochlorococcus (Chisholm et al., 1988; Goericke and Repeta, 1992; Ting et al., 2002). Because Prochlorococcus adapts to relatively deeper water enriched with blue light (400-500 nm; Ting et al., 2002), their isotopic signature could reflect that of the deep water nitrate/anmonium and thus differentiated from the majority of photoautotrophs dwelling in the shallower environment. Alternatively, 8-nor-DPEP could originate from bacteriochlorophyll- $a(\mathbf{8})$, because relative to the aromatic pyrrole ring of the chlorin structure of other chloropigments, the pyrroline ring of the bacteriochlorin structure of bacteriochlorophyll- $a$ is liable to 
cleavage of the ethyl group at the C-8 position (Kashiyama et al., 2007b).

\subsubsection{Origin of cycloheptanoDPEP $\left(13,15\right.$-ethano- $13^{2}, 17$ - propanoporphyrin)}

Figure $4 \mathrm{~b}$ shows clear differences in the isotopic compositions of cycloheptanoDPEP (2) and DPEP (1a). The mean $\Delta \Delta^{15} \mathrm{~N}$ and $\Delta^{13} \mathrm{C}$ values for cycloheptanoDPEP were $-0.9 \pm 0.6 \%$ and $-2.3 \pm 0.5 \%$, respectively $(1 \sigma ; n=7)$. Depletion in ${ }^{13} \mathrm{C}$ characterizes the isotopic composition of cycloheptanoDPEP. The observed discrepancy in carbon isotopic composition requires a depletion in ${ }^{13} \mathrm{C}$ of more than $50 \%$ in the additional carbon at the $\mathrm{C}-17^{3}$ position of $\mathrm{C}_{33}$ cycloheptanoDPEP in the case that it originates from the same source as that for DPEP; such a depletion is considered highly unlikely.

CycloheptanoDPEP (2) was also depleted in ${ }^{15} \mathrm{~N}$. Because all varieties of chlorophyllides are biosynthesized after 3,8divinylprotochlorophyllide (10), chloropigments and sedimentary porphyrins from a single source should have an identical $\delta^{15} \mathrm{~N}$ value. Indeed, in a study of single plant leaves, Chikaraishi et al. (2005a) reported no difference in the $\delta^{15} \mathrm{~N}$ values of chlorophylls- $a$ and $b$ ( $6 \mathbf{a}$ and $\mathbf{6 b}$ ). Moreover, the nitrogen isotopic signature is not expected to be altered during the degradation of chloropigments, because (1) nitrogen atoms are not exchangeable during degradation, and (2) no substantial isotopic discrimination of nitrogen has been observed during the demetallation of chlorophyllides (loss of magnesium) in a modern meromictic lake (Ohkouchi et al., 2005) and during the insertion of metal into octaethylporphyrin (Ni chelation) in a laboratory experiment (Kashiyama, 2006). We therefore conclude that cycloheptanoDPEP and DPEP (1a) in our samples originated from different photoautotrophic biomasses, although not necessarily from different compounds.

CycloheptanoDPEP (2) was first identified by Prowse et al. (1987). CycloheptanoDPEP and other bicycloalkanoporphyrins are commonly observed as the major components of vanadyl alkylporphyrins in many geological samples (VerneMismer et al., 1990; Sundararaman and Boreham, 1993; Sundararaman et al., 1994). Boreham et al. (1990) reported the carbon isotopic compositions of both vanadyl and nickel porphyrins from the Cretaceous Julia Creek oil shale, finding that vanadyl-chelated cycloheptanoDPEP and its potential analogs (i.e., 15,17-cycloheptanoporphyrin; 3a) were enriched in ${ }^{13} \mathrm{C}$ by $0.9-1.7 \%$ relative to vanadyl DPEP (1a), whereas the nickel-chelated equivalents were enriched in ${ }^{13} \mathrm{C}$ by $3.6 \%$ relative to nickel DPEP. Based on these isotopic data and the nature of their chemical structures, the authors concluded that chlorophylls- $c_{1-3}$ was the most likely source of cycloheptanoDPEP and other 15,17cycloheptanoporphyrins. In our datasets, however, the isotopic compositions of cycloheptanoDPEP are clearly different from those of 17-nor-DPEP (1e), the porphyrin derived from chlorophylls- $c$. This finding suggests that chlorophylls$c$ are not the main source of cycloheptanoDPEP in our samples.

In the Eocene Messel shale, Germany, and the Triassic Serpiano oil shale, Switzerland, 15,17cycloheptanoporphyrins ( $\mathbf{3 a}$ and $\mathbf{3 b}$ ) are enriched in ${ }^{13} \mathrm{C}$ by $3.62 \%$ and $3.54-3.68 \%$, respectively, relative to DPEP (1a; Hayes et al., 1987; Chicarelli et al., 1993). Significantly, the carbon isotopic composition of cycloheptanoDPEP (2) and its analogues are distinct from that of DPEP in all studies, although in different senses (i.e., whether depleted or enriched in $\left.{ }^{13} \mathrm{C}\right)$. Furthermore, relatively small $\delta^{13} \mathrm{C}$ differences between these compounds have also been reported in other cases; namely, 15,17-cycloheptanoporphyrins from the Cretaceous Julia Creek oil shale (Ocampo et al., 1989) and cycloheptanoDPEP from Late Pliocene lacustrine sediment (Keely et al., 1994) were $0.4-0.8 \%$ onriched in ${ }^{13} \mathrm{C}$ and $0.4-0.6 \%$ o depleted in ${ }^{13} \mathrm{C}$, respectively, relative to DPEP. These isotopic differences suggest that these compounds represent distinct biomasses.

In modern aquatic environments, pheopigments that possess structures analogous to that of cycloheptanoDPEP (2) have been reported among the degradation products of chloropigments. Such pheopigments were first found in sponges $\left(13^{2}, 17^{3}\right.$-cyclopheophorbide- $a$ enol; 5a; Karuso et al., 1986) and the viscera of macrobenthic suspension feeders (chlorophyllone- $a$; 4; Sakata et al., 1990; Yamamoto et al., 1992), and subsequently in marine and lacustrine surface sediments (chlorophyllone- $a$; 4; Chillier et al., 1993; Harris et al., 1995; Aydin et al., 2003; and $13^{2}, 17^{3}$ cyclopheophorbide $a$ enol; 5; and its analogs; Ocampo et al., 1997, 1999; Goericke et al., 2000) and sinking particles and particulate organic matter (chlorophyllone- $a$; Walker and Keely, 2004; and $13^{2}, 17^{3}$-cyclopheophorbide- $a$ enol; Goericke et al., 2000). Goericke et al. (2000) demonstrated that (1) $13^{2}, 17^{3}$-cyclopheophorbide enol was not detected in pure algal cultures, but that (2) the fecal materials of various micro- and macrozooplanktons in pure cultures contain a significant amount (40-71\% of the total pheopigments). Taken together, these results suggest that chlorophyllone and $13^{2}, 17^{3}$-cyclopheophorbide enol could be transformed in significant quantities from virtually all of the chloropigments via diverse herbivorous grazing activities. These compounds would eventually have been preserved in sedimentary rocks as cycloheptanoDPEP (2) or its analogs after reduction of the five- and seven-member rings and full aromatization of the chlorin unit.

If cycloheptanoDPEP (2) was specifically derived from grazing on photoautotrophs, its isotopic compositions should reflect those of the photoautotrophs consumed by herbivorous grazers. Therefore, the difference in isotopic composition between cycloheptanoDPEP and DPEP (1a) recorded in the present case suggests that grazing activities were not uniformly imposed on the entire population of photoautotrophs, but was biased in favor of a unique sub-population. This bias 
Table 4. Observed and estimated values of various carbon isotopic terms discussed in the text.

\begin{tabular}{|c|c|c|c|c|c|c|c|c|c|}
\hline & & $\delta_{D P E P}(\% \circ)$ & $\delta_{\text {cell }}(\% o)$ & \multicolumn{3}{|c|}{$\delta_{d}(\% o)$} & \multicolumn{3}{|c|}{$\varepsilon_{p}(\% o)$} \\
\hline & & (observed) & $\left(\right.$ estimated $\left.^{1}\right)$ & (estim & $\left.t e d^{2}\right)$ & & (est & ated $^{3}$ & \\
\hline \multicolumn{10}{|l|}{ Horizon 1} \\
\hline \multirow[t]{2}{*}{ BA138b } & & -17.1 & -18.9 & -5.5 & $\sim$ & -9 & 10 & $\sim$ & 13 \\
\hline & III & -17.8 & -19.6 & -5.5 & $\sim$ & -9 & 11 & $\sim$ & 14 \\
\hline \multirow[t]{2}{*}{ BA140a } & IV & -17.8 & -19.6 & -5.5 & $\sim$ & -9 & 11 & $\sim$ & 14 \\
\hline & $\mathrm{V}$ & -17.9 & -19.7 & -5.5 & $\sim$ & -9 & 11 & $\sim$ & 14 \\
\hline GJ01-7 & & -15.6 & -17.4 & -5.5 & $\sim$ & -9 & 8 & $\sim$ & 12 \\
\hline GJ01-3 & & -15.6 & -17.4 & -5.5 & $\sim$ & -9 & 8 & $\sim$ & 12 \\
\hline GJ01-G & & -15.8 & -17.6 & -5.5 & $\sim$ & -9 & 9 & $\sim$ & 12 \\
\hline
\end{tabular}

The lowest and highest estimated values of $\delta_{d}, \varepsilon_{p}$ are indicated assuming (1) ;SST in the Onnagawa basin was in the range of $10-20^{\circ} \mathrm{C}$; and (2) $\delta_{c}$ value approximately $1 \%$ o higher than the modern value (Kennett, 1986; Woodruff and Savin, 1989, 1991; Hodell and Vayavananda, 1994).

1: $\delta_{\text {cell }}=\delta_{\text {DPEP }}-1.8(\% o)$

2: $\delta_{d}=\delta_{c}+\left(\varepsilon_{b / c}+\varepsilon_{d / b} \delta\right)=\delta_{c}+\left(\left[653.627 /(T-233.45)^{2}\right]+0.22\right)+(24.12-9866 / T)(\% o)$;

after Thode et al. (1965) and Mook et al. (1974).

3: $\varepsilon_{p}=\delta_{\text {cell }}-\delta_{d}(\% o)$

may have resulted from spatial and temporal variability in grazing efficiency. Accordingly, both the taxonomic compositions of the photoautotrophs and their physiology should have been differentiated along with physicochemical parameters of the ambient sea water. Thus, the isotopic compositions of photoautotrophic populations would have varied spatially (i.e., variation along depth) and temporally within the water column. If grazing activity was more significant in a particular environment of the water column than others, it could have resulted in the differentiation of the isotopic compositions of cycloheptanoDPEP from those of DPEP. A1ternatively, such distinct isotopic compositions may reflect selective grazing on isotopically distinct groups of photoautotrophs within a community (Buffan-Dubau et al., 1996; Nomaki et al., 2006). To determine between these alternatives, further investigations are required into the isotopic compositions of early degradation products in the water column and surface sediment in the modern environment; the results of such analyses with clarify the potential use of this porphyrin as a proxy for paleoecology.

4.2 Nitrogen cycle associated with photosynthetic production

The Onnagawa Formation contains DPEP (1a) as the primary component of vanadyl porphyrins. As discussed above, although chlorophyll- $a$ is expected to be the dominant precursor of DPEP, it is also possible for DPEP to be derived from most of the other chloropigments. Thus, the isotopic compositions of DPEP are likely to reflect the average isotopic value for the entire photoautotrophic community at the time that the sediments were deposited. In this section, we dis- cuss the nitrogen isotopic signature of DPEP with the aim of interpreting the flow and transformation of nitrogen species throughout the entire system of photosynthetic primary production and hence the nitrogen cycle in the paleo-ocean.

Theoretically, the nitrogen isotopic composition of the cells of photoautotrophs reflects (1) that of the substrates (i.e., nitrate, nitrite, ammonia, or dinitrogen), and (2) processes associated with nitrogen uptake; namely, which nitrogen species were utilized in the growth and reproduction of the cell and how they were utilized. Thus, any interpretation of the nitrogen isotopic record of sedimentary porphyrins requires the careful separation of these two signals. Considering a $4.8 \%$ o depletion of ${ }^{15} \mathrm{~N}$ in the tetrapyrrole macrocycle of chlorophylls relative to the whole cell through biosynthesis (Ohkouchi et al., 2006), the $\delta^{15} \mathrm{~N}$ ranges of the photoautotrophic community estimated from those of DPEP are -2 to $-1 \%$ in Horizon 1 and -1 to $1 \%$ in Horizon 2 (Fig. 5; Table 4). It should be noted that there are some uncertainty in these reconstructions due to the natural variation in $\delta^{15} \mathrm{~N}$ difference between the chlorophylls and the cell $( \pm 1.4 \%$; $1 \sigma$, $n=20$ ); hence, the estimates may be somewhat wider ranges than these values. Here, we propose three scenarios that potentially explain these findings.

The first scenario involves a low $\delta^{15} \mathrm{~N}$ value $(\sim 0 \%$ o for nitrate in the surface water. In this case, it is also possible that the assimilated nitrogen has a low $\delta^{15} \mathrm{~N}$ value $(\sim 0 \%)$ under a nitrate-limited growth condition. In the modern ocean, however, such a low $\delta^{15} \mathrm{~N}$ value is rarely found for nitrate in surface waters, reflecting the relatively high $\delta^{15} \mathrm{~N}$ value of nitrate in subsurface waters $(\sim+6 \%$; Liu and Kaplan, 1989; Sigman et al., 2000). In general, nitrate in oceanic water is enriched in ${ }^{15} \mathrm{~N}$ due to an denitrification process that se- 

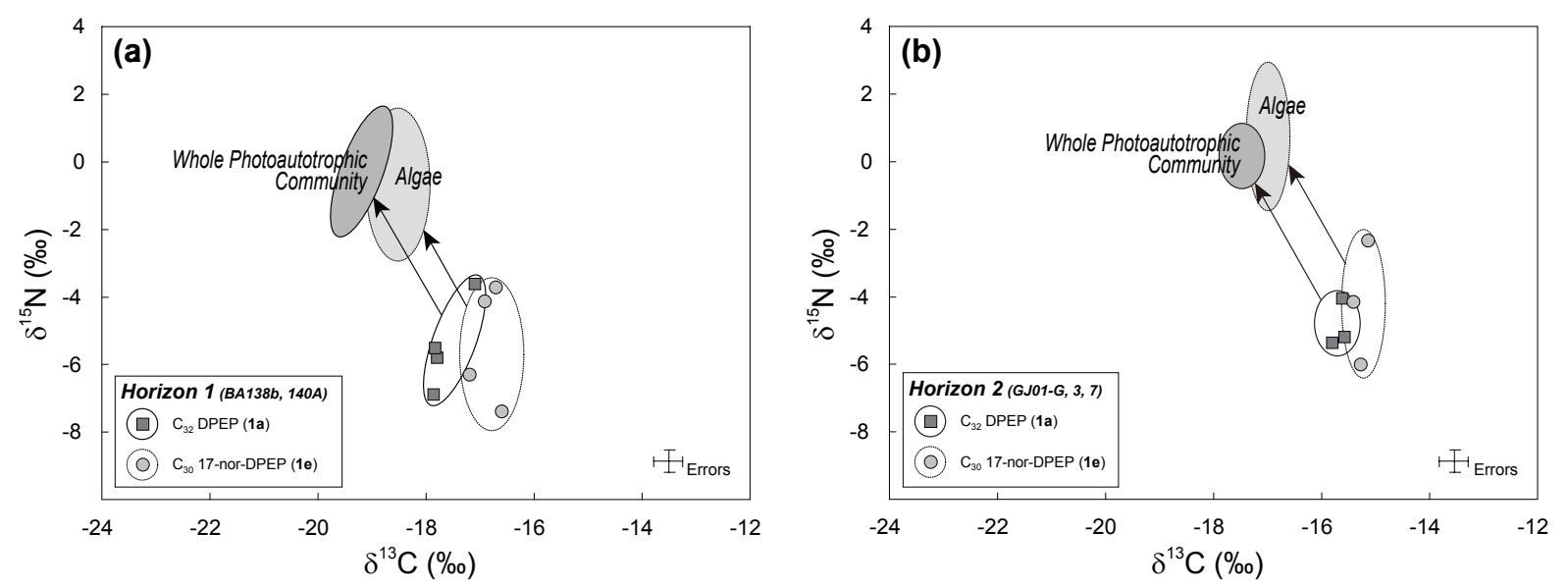

Fig. 5. Reconstructed $\delta^{15} \mathrm{~N}$ and $\delta^{13} \mathrm{C}$ values of photoautotrophic cells for: (a) samples from Horizon 1; and (b) samples from Horizon 2. Circles indicate approximate ranges of isotopic compositions for the photoautotrophic populations represented by individual porphyrin species.

lectively consumes ${ }^{14} \mathrm{NO}_{3}^{-}$with a large degree of isotopic fractionation, ranging from -30 to $-20 \%$ o (Cline and Kaplan, 1975; Liu and Kaplan, 1989; Brandes et al., 1998; Altabet et al., 1999; Barford et al., 1999; Voss et al., 2001; Sigman et al., 2003), leaving ${ }^{15} \mathrm{~N}$-enriched nitrate. The occurrence of relatively ${ }^{15} \mathrm{~N}$-enriched nitrate is likely in this case, because an oxygen-depleted water mass has been suggested for the Onnagawa Basin based on sedimentological evidence such as the occurrence of submillimeter-scale laminations in nearly $50 \%$ of the siliceous sediments within the Onnagawa Formation (Tada, 1991; Koshikawa, 2002).

The second scenario involves the limiting of primary production by factors other than nitrate availability, such as the availability of phosphate (Thingstad and Rassoulzadegan, 1995), iron (Martin et al., 1994), or zinc (Morel et al., 1994; Shaked et al., 2006). In this case, a relatively high degree of isotopic fractionation during incomplete nitrate consumption by photoautotrophs would have resulted in significant ${ }^{15} \mathrm{~N}$ depletion by -4 to $-10 \%$ for photoautotrophic cells relative to the source nitrate, which presumably had a positive $\delta^{15} \mathrm{~N}$ value. As discussed below, however, this scenario is inconsistent with inferences based on the carbon isotopic compositions of the porphyrins.

In the third scenario, the main source of nitrogen introduced into the net photosynthetic system is derived from an in situ $\mathrm{N}_{2}$-fixation process, with the result that the average $\delta^{15} \mathrm{~N}$ values of the photoautotrophs ( -2 to $+1 \%$ ) largely overlap with the expected $\delta^{15} \mathrm{~N}$ value of nitrogen assimilated via $\mathrm{N}_{2}$-fixation (-2 to 0\%; Wada and Hattori, 1991). The following two factors indicate that quantitatively significant diazotrophs in the surface ocean would have been cyanobacteria: (1) the structure of DPEP suggests that it primarily originated from chlorophylls rather than bacteriochlorophylls, and (2) diazotrophic photoautotrophs that produce chlorophylls are only found among cyanobacteria. The di- azotrophic cyanobacterium Trichodesmium forms blooms in oligotrophic open oceans, being a major source of new nitrogen in the modern tropical and subtropical oceans (Capone et al., 1997, 2005; Carpenter et al., 1997; Karl et al., 1997; Davis and McGillicuddy et al., 2006). Furthermore, unicellular cyanobacteria recognized in the open ocean play a potentially significant role in $\mathrm{N}_{2}$-fixation within oligotrophic environments (Zehr et al., 2001; Montoya et al., 2004).

Further constraints upon the ecology of photoautotrophs and the associated nitrogen cycle can be derived from the $\delta^{13} \mathrm{C}$ values of porphyrins, which reflect the physiology of photoautotrophs in terms of photosynthesis. Considering an approximately $1.8 \%$ enrichment of ${ }^{13} \mathrm{C}$ in the tetrapyrrole macrocycle of chlorophylls relative to the whole cell through biosynthesis (Ohkouchi et al., 2008), the $\delta^{13} \mathrm{C}$ ranges of the photoautotrophic community estimated from those of DPEP are -20 to $-19 \%$ in Horizon 1 and -18 to $-17 \%$ in Horizon 2. These ranges are somewhat less negative than those of modern marine suspended particulate organic matter (typically -25 to $-20 \%$ o in the mid-latitudes; Rau et al., 1982; Goericke and Fry, 1994).

Following the procedure of Kashiyama et al. (2008), we estimated the degree of overall isotopic fractionation during photosynthesis $\left(\varepsilon_{p}\right.$ value) to be 10 to $14 \%$ o for Horizon 1 and 8 to $12 \%$ for Horizons 2 (Table 4). In contrast, the likely range in $\varepsilon_{p}$ values for the middle Miocene was probably similar to that observed in the modern ocean (i.e., 14 to $20 \%$ in temperate oceanic water), given that atmospheric $p \mathrm{CO}_{2}$ for the middle Miocene ( 260 ppmv; Pagani et al., 1999) was similar to modern pre-industrial values.

The small $\varepsilon_{p}$ value calculated above for the Onnagawa Basin is incompatible with the occurrence of surface water with excess nitrate (the second scenario listed above). Indeed, elevated $\varepsilon_{p}$ values are observed in modern oceanic surface water with excess nitrate, such as in the Southern 
Ocean (south of the polar front; $55-65^{\circ} \mathrm{S}$ ), due in part to the ecological requirements of photoautotrophs (Popp et al., 1998, 1999). In contrast, small $\varepsilon_{p}$ values have been proposed for diazotrophic photoautotrophs in the modern oligotrophic oceans (the third scenario). The carbon isotopic composition of field-collected Trichodesmium, a colonial and bloomforming marine diazotrophic cyanobacterium, tends to be less negative than that of other photoautotrophs (Calder and Parker, 1973; Minagawa and Wada, 1986; Wada and Hattori, 1991). In a unique case, Carpenter et al. (1997) reported a $\delta^{13} \mathrm{C}$ value of $-12.9 \pm 1.1 \%$ o $(1 \sigma, n=10$; range from -15.2 to $11.9 \%$ ) for Trichodesmium cells from stratified oligotrophic surface waters of the southeast North Atlantic Ocean and the northwestern Caribbean Sea, indicating a $\varepsilon_{p}$ value of $<10 \%$. These values invoke special mechanisms associated with carboxylation that express characteristically low degrees of carbon isotopic fractionation (Carpenter et al., 1997).

Kashiyama et al. (2008) discussed the enzymatically catalyzed active transport of $\mathrm{CO}_{2}(\mathrm{aq}) / \mathrm{HCO}_{3}^{-}$into the cell, and the manifestation of an alternative carboxylation enzyme, phosphoenolpyruvate carboxylase (PEPC; i.e., $\beta$ carboxylation), as the processes responsible for the small $\varepsilon_{p}$ value described above, as these processes are common among cyanobacteria. It is recognized that numerous algal species are capable of active transport (Badger, 1987), and it is known to be ubiquitous among cyanobacteria ( $\mathrm{Ka}-$ plan et al., 1993; Ogawa and Kaplan, 2003 and references therein). With active transport, much of the $\mathrm{CO}_{2}(\mathrm{aq}) / \mathrm{HCO}_{3}^{-}$ pulled into the cell would be committed to carboxylation. In such a case, the degree of isotopic fractionation should generally become significantly small ( $\sim 5 \%$; Sharkey and Berry, 1985; , being controlled largely by the isotopic effect associated with the enzyme responsible for active transport and the proportion of $\mathrm{CO}_{2}(\mathrm{aq})$ leaked from the cell (Hayes et al., 1993). PEPC is known to be an important enzyme among cyanobacteria, as it facilitates the $\beta$-carboxylation of phosphoenolpyruvate to produce oxaloacetate, a precursor of glutamate in the tricarboxylic acid cycle (Colman, 1989; Tabita, 1994). The $\beta$-carboxylation process uses isotopically heavy $\mathrm{HCO}_{3}^{-}$as a substrate, resulting in small $\varepsilon_{f}$ values $(\sim 5 \%$; Raven, 1997).

In conclusion, diazotrophic cyanobacteria are likely to have made a substantial contribution to primary production in the middle Miocene Onnagawa Basin; thus, the nitrogen utilized in photosynthetic primary production was supplied mostly via in situ $\mathrm{N}_{2}$-fixation by diazotrophic cyanobacteria.

\subsection{Oceanographic implications}

The prevalence of the $\mathrm{N}_{2}$-fixation process in the photosynthetic system strongly suggests the presence of nitratedeficient, oligotrophic surface waters in the middle Miocene Onnagawa Basin. The high energy demands of $\mathrm{N}_{2}$-fixation (Tyrrell, 1999) mean that diazotrophic cyanobacteria are only able to out-compete non-diazotrophic algae when nitrate is highly limited. In the modern environment, diazotrophic cyanobacteria (Trichodesmium in particular) are distributed throughout the tropical and subtropical Atlantic, Pacific, and Indian Oceans, and the Caribbean and South China Seas (Capone et al., 1997). In these regions the surface water is density stratified, thereby preventing access to nitrate from the deep ocean. In fact, the periodic occurrence of wellpreserved fine-scaled laminations within the Onnagawa Formation suggests the intermittent development of an anaerobic environment in the bottom water of the Onnagawa Basin (Tada, 1991; Koshikawa, 2002).

These characteristics of the middle Miocene Onnagawa Formation are similar to those of Pleistocene Mediterranean sapropels. The origin of this organic-rich anaerobic sediment has been explained in terms of extensive $\mathrm{N}_{2}$-fixation by diazotrophic cyanobacteria and the production of oligotrophic diatom species in stratified surface water (Kemp et al., 1999; Sachs and Repeta, 1999). Furthermore, in the study of the Cretaceous ocean anoxic events, Kashiyama et al. (2008) suggested significance of $\mathrm{N}_{2}$-fixation by diazotrophic cyanobacteria in stratified anoxic basins during formation of the organic-rich black shales based on the isotopic signatures of DPEP. These three examples commonly correlate $\mathrm{N}_{2}$-fixation by diazotrophic cyanobacteria and formation of highly organic-rich anaerobic sediments despite differences in ages and basin scales. Although it is not observed in modern oceans, the diazotrophic cyanobacteria-promoted production may have been one of the major biogeochemical processes leading mass sequestration of organic carbon into the sediments in geological pasts.

\subsection{Ecological implications}

The Onnagawa Formation is characterized by relatively abundant 17-nor-DPEP (1e; 8.6-16.7\%; Fig. 3), presumably a derivative of chlorophylls- $c_{1-3}(\mathbf{7 a - c})$. Considering the chlorophyll- $a$ : $c$ molar ratio in chlorophylls- $c$-producing algae (ranging from 2.5:1 to 4:1; Boczar and Prezelin, 1987), a large proportion (30-80\%) of porphyrins may have been derived from chlorophylls- $c$-producing algae; however, this range may be an overestimate because the fully aromatic tetrapyrrole macrocycles of chlorophylls- $c$ (i.e., porphyrin) have a higher preservation potential than chlorophyll- $a$, which is a partially saturated equivalent (i.e., chlorin). This suggests a significant contribution of chlorophylls- $c$ producing algae to photosynthetic production, consistent with previous works that propose the predominance of diatoms in terms of primary production during the deposition of the Onnagawa Formation (Tada, 1991; Koshikawa, 2002). The Onnagawa Formation is dominated by biogenic silica derived from diatoms (20-60\%; Table 1; Tada, 1991), which are the representative chlorophyll-c-producing marine algae. Furthermore, Suzuki (1993) reported abnormally high 
concentration of 24-norcholestane in this formation and suggested the dominance of diatoms in primary production.

Our data, however, also suggest the presence of other nonchlorophyll-c-producing photoautotrophs. If diatoms (or other chlorophyll- $c$-producing algae) had been the sole dominant primary producer, DPEP (1a) would also have been derived from the chlorophylls of these algae; hence, the isotopic compositions of DPEP and 17-nor-DPEP would have been identical. However, the obtained $\delta^{13} \mathrm{C}$ values of DPEP and 17-nor-DPEP demonstrated slight but statistically significant differences (Fig. 4). In addition, other quantitatively important porphyrins, such as 8-nor DPEP and cycloheptanoDPEP, have isotopic compositions distinct from those of 17-nor-DPEP (Fig. 4). These findings suggest that the phototrophic community at the time of sediment deposition consisted of various groups, including chlorophylls- $c$-producing algae. Indeed, as discussed above, the obtained isotopic signatures of DPEP suggest a substantial component of diazotrophic cyanobacteria in the photoautotrophic community.

It is noteworthy that the nitrogen isotopic composition of chlorophylls- $c$-producing algae $(-3$ to $+1 \%$ ofor Horizon 1 and -1 to $+3 \%$ for Horizon 2; Table 4) reconstructed from that of 17-nor-DPEP (1e) is close to or overlaps with that of typical diazotrophs. Because biological $\mathrm{N}_{2}$-fixation is an exclusively prokaryotic metabolic process (Postgate, 1998), it could be proposed that the growth of such non-diazotrophic photoautotrophs was supported chiefly by regenerated nitrogen that was ultimately derived from diazotrophs. The reconstructed $\delta^{15} \mathrm{~N}$ values of chlorophylls- $c$-producing algae are more variable than those calculated for the entire photoautotrophic community (Fig. 5), and the reconstructed $\delta^{15} \mathrm{~N}$ value of algae for sample GJ01-7 from Horizon 2 is $\sim+2.5 \%$, falling outside of the range for diazotrophs-derived fixed nitrogen. The slightly elevated $\delta^{15} \mathrm{~N}$ value of 17-nor-DPEP can be attributed to the partial and variable utilization of the advected nitrate during algal growth.

The source of new nitrogen entering the photosynthetic system in the modern oligotrophic ocean is largely cyanobacterial $\mathrm{N}_{2}$-fixation, with a lesser contribution from nitrate flux from the deep sea (e.g., Capone et al., 2005; Davis and McGillicuddy, 2006). The nitrogen derived from $\mathrm{N}_{2}$-fixation is accumulated and recycled in the surface water, resulting in isotopically light nitrogen pools of particulate organic nitrogen (typically 0 to $+2 \%$; Capone et al., 1997 and references therein; Mino et al., 2003; Meador et al., 2007) or reactive high-molecular-weight dissolved organic nitrogen (2.5\%); Meador et al., 2007). Furthermore, algal blooms commonly co-exist with diazotrophic cyanobacteria such as Trichodesmium spp. and Richelia intracellularis in modern oligotrophic surface water (e.g., Scharek et al., 1999; Foster et al., 2007). These findings indicate that algal communities that include chlorophyll-c-producing groups depend on the bioavailable nitrogen (e.g., ammonium and nitrate) with low $\delta^{15} \mathrm{~N}$ values that is supplied into the system by diazotrophic cyanobacteria (e.g., Venrick, 1974).
We further suggest that diatoms and associated symbiotic cyanobacteria might have been responsible for the formation of the biogenic-silica-rich Onnagawa Formation. Symbioses between cyanobacteria and various marine algae are widespread in modern oligotrophic oceans, whereby $\mathrm{N}_{2-}$ fixation by symbionts benefits the host organism (Taylor, 1982; Martinez et al., 1983; Villareal, 1992; Buck and Bentham, 1998; Scharek et al., 1999; Carpenter and Janson, 2000; Carpenter, 2002; Gomez et al., 2005). In particular, diatoms such as Rhizosolenia and Hemiaulus (which host the endosymbiotic cyanobacteria Richelia intracellularis) form blooms in modern oligotrophic oceans, possibly playing a major role in the nitrogen cycle in the surface ocean (Carpenter et al., 1999; Foster et al., 2007; White et al., 2007). For example, an extensive bloom of the Hemiaulus/Richelia association was observed off the northeast coast of South America in the autumn of 1996, with an $\mathrm{N}_{2-}$ fixation rate as high as $3110 \mu \mathrm{mol} \mathrm{N} \mathrm{m}^{-2} \mathrm{~d}^{-1}$ (Carpenter et al., 1999). This rate is much higher than that of the Trichodesmium bloom in the North Atlantic Ocean $(239 \mu \mathrm{mol}$ $\mathrm{N} \mathrm{m}^{-2} \mathrm{~d}^{-1}$; Capone et al., 2005). The average $\delta^{15} \mathrm{~N}$ value of the Hemiaulus/Richelia association was $-1.24 \%$, a typical value for diazotrophic photoautotrophs. Furthermore, Pancost et al. (1997) reported that diatoms experiencing such a high growth rate employ active transport for the acquisition of inorganic carbon and exhibit exceptionally low degrees of carbon fractionation, resulting in elevated $\delta^{13} \mathrm{C}$ values in their cells. Although diatom tissues were completely recrystallized in the section analyzed in the present study, diatoms reported from other parts of the Onnagawa Formation and its equivalent formations in adjacent areas include $R$ hizosolena and Coscinodiscus (Uemura and Sawamura, 1973; Koizumi and Matoba, 1989), of which modern species are known to contain symbiotic cyanobacteria in their cells (Villareal, 1992; Carpenter, 2002).

\section{Conclusions}

In the present study, the nitrogen and carbon isotopic compositions of DPEP (1a) provide evidence that new nitrogen in the system of photoautotrophic primary production was mainly supplied via biological $\mathrm{N}_{2}$-fixation by diazotrophic cyanobacteria. The $\delta^{15} \mathrm{~N}$ value of DPEP (1a) indicates that the $\delta^{15} \mathrm{~N}$ value of the entire photoautotrophic community was -2 to $+1 \%$, which is close to or within the range of $\delta^{15} \mathrm{~N}$ values for organic matter produced by diazotrophs. Based on the $\delta^{13} \mathrm{C}$ value of DPEP, we estimated the degree of isotopic fractionation associated with carbon fixation by the photoautotrophic community to be 8 to $14 \%$, indicating elevated rates of $\beta$-carboxylation and/or active transport of the carbon substrates, which is typical of cyanobacteria. Both the nitrogen and carbon isotopic compositions of DPEP are therefore consistent with the proposal that diazotrophic cyanobacteria made a substantial contribution to primary production. 


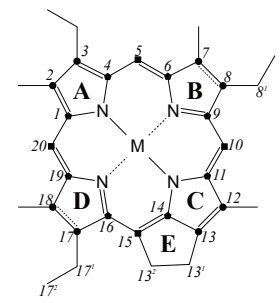

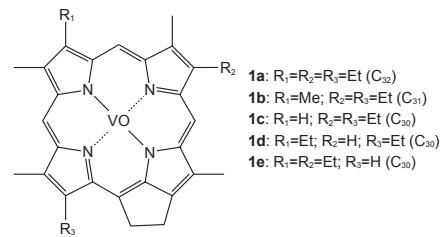

DPEP-type Porphyrins (1a-e)

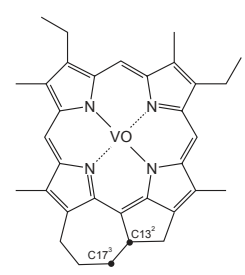

CycloheptanoDPEP (2)

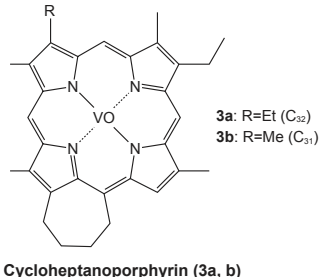

Cycloheptanoporphyrin (3a, b)

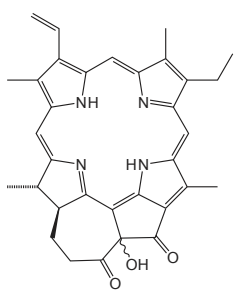

Chlorophyllone (4)

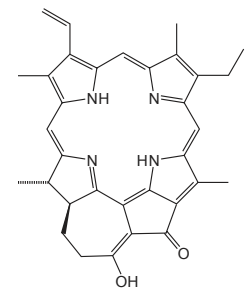

$13^{2}, 17^{3}$-Cyclopheophorbide enols $(5)$

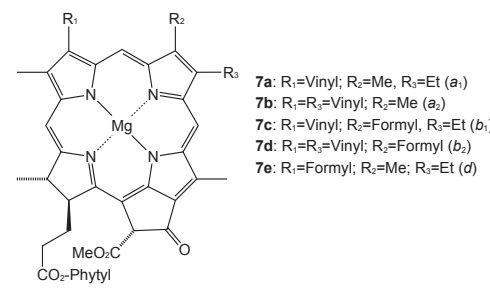

Chlorophylls $a, b$, and $d(6 a-e)$

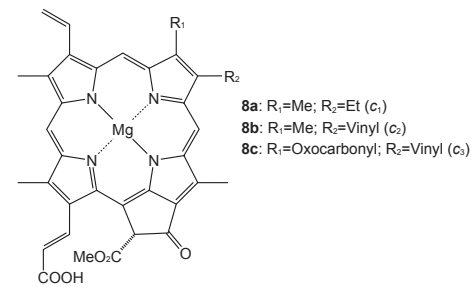

Chlorophylls $c(7 a-c)$

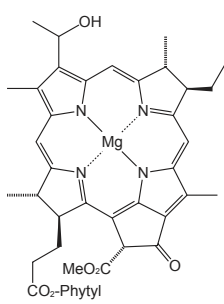

Bacteriochlorophylls a (8)

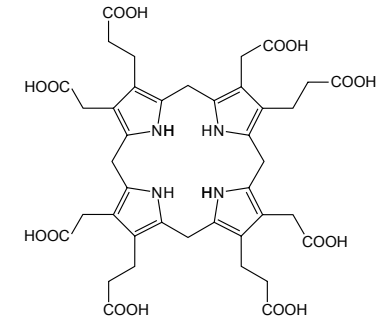

Uroporphyrinogen III (9)

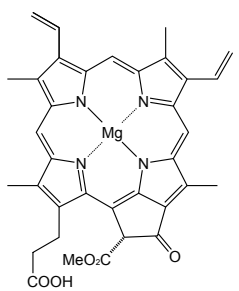

3,8-Divinylchlorophyllide (10)

Fig. A1. Chemical Structures

This suggests in turn that the surface water of the middle Miocene Onnagawa Basin received only a minor supply of nitrate from deep water because of thermohaline stratification.

The nitrogen isotopic composition of 17-nor-porphyrin indicates that chlorophyll- $c$-producing algae, the presumed sole source of this compound, thrived on the regenerated ammonium and/or nitrate sourced from co-existing diazotrophic cyanobacteria. Considering the great abundance of biogenic silica in the Onnagawa Formation, diatoms probably constituted the majority of the chlorophyll-c-producing algae at the time of deposition. Thus, we infer that the diatoms may have hosted diazotrophic cyanobacteria (i.e., Richelia intracellularis), as commonly observed in modern oligotrophic oceans.

Our results also demonstrate that the isotopic signatures of two other sedimentary porphyrins, cycloheptanoDPEP (2) and 8-nor-DPEP (1d), provide information on specific biogeochemical/ecological processes that operated during deposition of the sediments. The isotopic compositions of cycloheptanoDPEP (2), the probable products of herbivorous grazing of chlorophylls, are distinct from those of DPEP (1a), despite their presumed common origin. This finding indicates that cycloheptanoDPEP are likely to represent a specific population within the phototrophic community, possibly selective grazing on specific photoautotrophs by herbivores.
In general, the occurrence of isotopic discrepancies between two porphyrins with presumably identical precursors suggests that the isotopic signatures of the sedimentary porphyrins might reflect pre-depositional (or syn-depositional?) oceanic processes in addition to source information.

Although 8-nor-DPEP (1d) is potentially a unique biomarker, it is currently difficult to further constrain its origin (i.e., Prochlorococcus vs. aerobic photoheterotrophic bacteria) because the ecology and isotopic signatures of these potential source organisms are poorly understood. Prochlorococcus is a quantitatively important primary producer that dwells in deeper parts of the photic zone in the oligotrophic ocean (100-200 m; Campbell et al., 1994; Partensky et al., 1999), being peculiar in that it is incapable of growing on nitrate (Ting et al., 2002). Aerobic photoheterotrophic bacteria are potentially an important producer in the upper open ocean (Kolber et al., 2001); however, their ecology in the marine environment is poorly understood. Thus, the isotopic compositions of both photoautotrophs are expected to be unique in the natural environment.

The method employed in the present study made use of the isotopic compositions of individual sedimentary porphyrins as proxies for the biogeochemistry and ecology of the photoautotrophic community of the paleo-ocean (e.g., Kashiyama et al., 2008); however, interpretations of isotopic 
data for porphyrins are strongly dependent on our limited knowledge of the ecology and physiology of individual groups of photoautotrophs and their isotopic signatures in natural environments. In fact, the compound-specific isotopic analysis of chloropigments from natural samples is an emerging method in elucidating biogeochemical processes in the modern aquatic environment (Sachs et al., 1999; Sachs and Repeta, 1999; Chikaraishi et al., 2005a; Ohkouchi et al., 2005; York et al., 2007). Such an approach has the potential to both resolve modern processes related to photosynthetic primary production and provide a basis for isotopic analyses of porphyrins with the aim of resolving processes associated with photosynthetic primary production in the paleo-ocean.

Acknowledgements. We thank S. Nomoto, H. Kawahata, K. Sugiura, E. Tajika, Y. Yokoyama, and Y. Chikaraishi for their valuable advice, T. Koshikawa for kindly providing rock samples, and H. Suga for technical support. We are deeply indebted to two anonymous reviewers for their critical reviews and advice. This study was financially supported by a Grant-in-Aid for Creative Scientific Research (19GS0211), JOGMEC, and JSPS.

Edited by: J Bijma

\section{References}

Altabet, M. A., Pilskaln, C., Thunell, R., Pride, C., Sigman, D., Chavez, F., and Francois, R.: The nitrogen isotope biogeochemistry of sinking particles from the margin of the eastern North Pacific, Deep Sea Res. Part I, 46, 655-679, 1999.

Aydin, N., Daher, S., and Gulacar, F.: On the sedimentary occurrence of chlorophyllone- $a$, Chemosphere, 52, 937-942, 2003.

Badger, M. R.: The $\mathrm{CO}_{2}$-concentrating mechanism in aquatic phototrophs, in: The Biochemistry of Plants: A Comprehensive Treatise, 10, Photosynthesis, Academic Press, New York, 219274, 1987.

Baker, E. W. and Louda, J. W.: Porphyrins in the geological record, in: Biological Markers in Sediments, Meth. Geochem. Geophys., 24, Elsevier, Amsterdam, 125-225, 1986.

Baker, E. W. and Palmer, S. E.: Geochemistry of porphyrins, in: The Porphyrins, I, Academic Press, New York, 486-552, 1978.

Barford, C. C., Montoya, J. P., Altabet, M. A., and Mitchell, R.: Steady-state nitrogen isotope effects of $\mathrm{N}_{2}$ and $\mathrm{N}_{2} \mathrm{O}$ production in Paracoccus denitrificans, Appl. Environ. Microbiol., 65, 989994, 1999.

Beale, S. I.: Biosynthesis and structures of porphyrins and heme, in: Anoxygenic Photosynthetic Bacteria, Kluwer Academic Publishers, Netherland, 153-177, 1995.

Bidigare, R. R., Fluegge, A., Freeman, K. H., Hanson, K. L., Hayes, J. M., Hollander, D., Jasper, J. P., King, L. L., Laws, E. A., Milder, J., Millero, F. J., Pancost, R., Popp, B. N., Steinberg, P. A., and Wakeham, S. G.: Consistent fractionation of ${ }^{13} \mathrm{C}$ in nature and in the laboratory: Growth-rate effects in some haptophyte algae, Global Biogeochem. Cycles, 11, 279-292, 1997.

Bidigare, R. R., Fluegge, A., Freeman, K. H., Hanson, K. L., Hayes, J. M., Hollander, D., Jasper, J. P., King, L. L., Laws, E. A., Milder, J., Millero, F. J., Pancost, R., Popp, B. N., Steinberg,
P. A., and Wakeham, S. G.: Erratum: "Consistent fractionation of ${ }^{13} \mathrm{C}$ in nature and in the laboratory: Growth-rate effects in some haptophyte algae", Global Biogeochem. Cycles, 13, 251252, 1999.

Bidigare, R. R., Kennicutt II, M. C., and Keeney-Kennicutt, W. L.: Isolation and purification of chlorophylls- $a$ and $b$ for the determination of stable carbon and nitrogen isotope compositions, Anal. Chem., 63, 130-133, 1991.

Boczar, B. A. and Prezelin, B. B.: Chlorophyll-protein complexes from the red-tide dinoflagellate, Gonyaulax polyedra stein, Plant Physiol., 83, 805-812, 1987.

Boreham, C. J., Fookes, C. J. R., Popp, B. N., and Hayes, J. M.: Origins of etioporphyrins in sediments: evidence from stable carbon isotopes, Geochim. Cosmochim. Acta, 53, 2451-2455, 1989.

Boreham, C. J., Fookes, C. J. R., Popp, B. N., and Hayes, J. M.: Origin of petroporphyrins, 2. Evidence from stable isotopes, Energy Fuels, 4, 658-661, 1990.

Brandes, J. A., Devol, A. H., Yoshinari, T., Jayakumar, D. A., and Naqvi, S. W. A.: Isotopic composition of nitrate in the central Arabian Sea and eastern tropical North Pacific: a tracer for mixing and nitrogen cycles, Limnol. Oceanogr., 43, 1680-1689, 1998.

Buck, K. and Bentham, W. N.: A novel symbiosis between a cyanobacterium, Synechococcus sp., an aplastidic protist, Solenicola setigera, and a diatom, Leptocylindrus mediterraneus, in the open ocean, Mar. Biol., 132, 349-355, 1998.

Buffan-Dubau, E., de Wit, R., and Castel, J.: Feeding selectivity of the harpacticoid copepod Canuella perplexa in benthic muddy environments demonstrated by HPLC analyses of chlorin and carotenoid pigments, Mar. Ecol. Prog. Ser., 137, 71-82, 1996.

Calder, J. A. and Parker, P. L.: Geochemical implications of induced changes in $\mathrm{C}^{13}$ fractionation by blue-green algae, Geochim. Cosmochim. Acta, 37, 133-140, 1973.

Callot, H. J. and Ocampo, R.: Geochemistry of porphyrins, in: The Porphyrin Handbook, 1, Synthetic and Organic Chemistry, Chap. 7, Academic Press, New York, 349-398, 2000.

Campbell, L., Nolla, H. A., and Vaulot, D.: The importance of Prochlorococcus to community structure in the central North Pacific Ocean, Limnol. Oceanogr., 39, 954-961, 1994.

Capone, D. G., Burns, J. A., Montoya, J. P., Subramaniam, A., Mahaffey, C., Gunderson, T., Michaels, A. F., and Carpenter, E. J.: Nitrogen fixation by Trichodesmium spp.: An important source of new nitrogen to the tropical and subtropical North Atlantic Ocean, Global Biogeochem. Cycles, 19, GB2024, doi:10.1029/2004GB002331, 2005.

Capone, D. G., Zehr, J., Paerl, H., Bergman, B., and Carpenter, E. J.: Trichodesmium: A globally significant marine cyanobacterium, Science, 276, 1221-1229, 1997.

Carpenter, E. J.: Marine cyanobacterial symbiosis, Biol. Environ.: Proc. Royal Irish Acad., 102B, 15-18, 2002.

Carpenter, E. J., Harvey, H. R., Fry, B., and Capone, D. G.: Biogeochemical tracers of the marine cyanobacterium Trichodesmium, Deep-Sea Res. I, 44, 27-38, 1997.

Carpenter, E. J. and Janson, S.: Intracellular cyanobacterial symbionts in the marine diatom Climacodium frauenfeldianum Grunow, J. Phycol., 36, 540-544, 2000.

Carpenter, E. J., Montoya, J. P., Burns, J., Mulholland, M. R., Subramaniam, A., and Capone, D. G.: Extensive bloom of a $\mathrm{N}_{2-}$ fixing diatom/cyanobacterial association in the tropical Atlantic 
Ocean, Mar. Ecol. Prog. Ser., 185, 273-283, 1999.

Chamberlain, P. M., McNamara, N. P., Chaplow, J., Stott, A. W., and Black, H. I. J.: Translocation of surface litter carbon into soil by Collembola, Soil Biol. Biochem., 38, 2655-2664, 2006.

Chicarelli, M. I., Hayes, J. M., Popp, B. N., Eckardt, C. B., and Maxwell, J. R.: Carbon and nitrogen isotopic compositions of alkyl porphyrins from the Triassic Serpiano oil shale, Geochim. Cosmochim. Acta, 57, 1307-1311, 1993.

Chikaraishi, Y., Matsumoto, K., Ogawa, N. O., Suga, H., Kitazato, H., and Ohkouchi, N.: Hydrogen, carbon and nitrogen isotopic fractionations during chlorophyll biosynthesis in $\mathrm{C} 3$ higher plants, Phytochem., 66, 911-920, 2005a.

Chikaraishi, Y. and Naraoka, H.: $\delta^{13} \mathrm{C}$ and $\delta \mathrm{D}$ identification of sources of lipid biomarkers in sediments of Lake Haruna (Japan), Geochim. Cosmochim. Acta, 69, 3285-3297, 2005 b.

Chillier, X. F. D., Gulacar, F. O., and Buchs, A.: A novel sedimentary lacustrine chlorin: Characterization and geochemical significance, Chemosphere, 27, 2103-2110, 1993.

Chisholm, S. W., Olson, R. J., Zettler, E. R., Goericke, R., Waterbury, J. B., and Welschmeyer, N. A.: A novel free-living prochlorophyte occurs at high cell concentrations in the oceanic euphotic zone, Nature, 334, 340-343, 1988.

Cifuentes, L. A., Fogel, M. L., Pennock, J. R., and Sharp, J. H.: Biogeochemical factors that influence the stable nitrogen isotope ratio of dissolved ammonium in the Delaware Estuary, Geochim. Cosmochim. Acta, 53, 2713-2721, 1989.

Cline, J. D. and Kaplan, I. R.: Isotopic fractionation of dissolved nitrate during denitrification in the eastern tropical North Pacific Ocean, Mar. Chem., 3, 271-299, 1975.

Colman, B.: Photosynthetic carbon assimilation and the suppression of photorespiration in the cyanobacteria, Aquat. Bot., 34, 211-231, 1989.

Davis, C. S. and McGillicuddy, D. J. Jr.: Transatlantic abundance of the $\mathrm{N}_{2}$-fixing colonial cyanobacterium Trichodesmium, Science, 312, 1517-1520, 2006.

Delwiche, C. C. and Steyn, P. L.: Nitrogen isotope fractionation in soils and microbial reactions, Environ. Sci. Technol., 4, 929-935, 1970.

Di Nello, R. K. and Dolphin, D.: Evidence for fast (major) and slow (minor) pathway in the Schumm devinylation reaction of vinylporphyrins, J. Org. Chem., 46, 3498-3505, 1981.

Eckardt, C. B., Keely, B. J., Waring, J. R., Chicarelli, M. I., and Maxwell, J. R. Preservation of chlorophyll-derived pigments in sedimentary organic matter, Phil. Trans., Loyal Soc. Lond. B, 333, 339-348, 1991.

Farquhar, G. D., Ball, M. C., Von Caemmerer, S., Roksandic, Z.: Effect of salinity and humidity on $\delta^{13} \mathrm{C}$ value of halophytes - evidence for diffusional isotope fractionation determined by the ratio of intercellular/atmospheric partial pressure of $\mathrm{CO}_{2}$ under different environmental conditions, Oecologia, 52, 121-124, 1982a.

Farquhar, G. D., O'Leary, M. H., and Berry, J. A.: On the relationship between carbon isotope discrimination and the intercellular carbon dioxide concentration in leaves, Australian J. Plant Physiol., 9, 121-137, 1982b.

Filer, C. N.: Isotopic fractionation of organic compounds in chromatography, J. Labelled Comp. Radiopharm., 42, 169-197, 1999.

Fookes, C. J. R.: Structure determination of nickel(II) deoxophylloerythroetioporphyrin and a $\mathrm{C}_{30}$ homologue from an oil shale:
Evidence that petroporphyrins are derived from chlorophyll, J. Chem. Soc., Chem. Comm., 1983, 1472-1473, 1983.

Foster, R. A., Subramaniam, A., Mahaffey, C., Carpenter, E. J., Capone, D. G., and Zehr, J. P.: Influence of the Amazon River plume on distributions of free-living and symbiotic cyanobacteria in the western tropical north Atlantic Ocean, Limnol. Oceanogr., 52, 517-532, 2007.

Freeman, K. H. and Hayes, J. M.: Fractionation of carbon isotopes by phytoplankton and estimates of ancient $\mathrm{CO}_{2}$ levels, Global Biogeochem. Cycles, 6, 185-198, 1992.

Gibbison, R., Peakman, T. M., and Maxwell, J. R.: Novel porphyrins as molecular fossils for anoxygenic photosynthesis., Tetrahedron Lett., 36, 9057-9060, 1995.

Goericke, R. and Fry, B.: Variations of marine plankton $\delta^{13} \mathrm{C}$ with latitude, temperature, and dissolved $\mathrm{CO}_{2}$ in the world ocean, Global Biogeochem. Cycles, 8, 85-90, 1994.

Goericke, R. and Repeta, D.: The pigments of Prochlorococcus marinus: the presence of divinyl chlorophyll- $a$ and $b$ in a marine prokaryote, Limnol. Oceanogr., 37, 425-434, 1992.

Goericke, R., Strom, S. L., and Bell, M. A.: Distribution and sources of cyclic pheophorbides in the environment, Limnol. Oceanogr., 45, 200-211, 2000.

Gómez, F., Furuya, K., and Takeda, S.: Distribution of the cyanobacterium Richelia intracellularis as an epiphyte of the diatom Chaetoceros compressus in the western Pacific Ocean, J. Plankton Res., 27, 323-330, 2005.

Guy, R. D., Fogel, M. L., Berry, J. A., and Hoering, T. C.: Isotope fractionation during oxygen production and consumption by plants, Prog. Phytosyn. Res. III., 9, 597-600, 1987.

Harris, P. G., Pearce, G. E. S., Peakman, T. M. and Maxwell, J. R.: A widespread and abundant chlorophyll transformation product in aquatic environments, Org. Geochem., 23, 183-187, 1995.

Hare, P. E., Fogel, M. L., Stafford, T. W., Mitchell, A. D., and Hoering, T. C.: The isotopic composition of carbon and nitrogen in individual amino acids isolated from modern and fossil proteins, J. Archaeol. Sci., 18, 211-292, 1991

Hayes, J. M.: Factors controlling ${ }^{13} \mathrm{C}$ contents of sedimentary organic compounds: Principles and evidence, Mar. Geol., 113, 111-125, 1993.

Hayes, J. M., Takigiku, R., Ocampo, R., Callot, H. J., and Albrecht, P.: Isotopic compositions and probable origins of organic molecules in the Eocene Messel shales, Nature, 329, 4851, 1987.

Hoch, M. P., Fogel, M. L., and Kirchiman, D. L.: Isotope fractionation associated with ammonium uptake by a marine bacterium, Limnol. Oceanogr., 37, 1447-1459, 1992.

Hodell, D. A. and Vayavananda, A.: Early middle Miocene paleoceanography of the western equatorial Pacific (DSDP site 289) and the evolution of Globorotalia (Fohsella), Mar. Micropaleontol., 22, 279-310, 1994.

Hoering, T. C. and Ford, H. T.: The isotope effect in the fixation of nitrogen by Azotobacter, J. Am. Chem. Soc., 82, 376-378, 1960.

Hoyt, P.B.: Chlorophyll-type compounds in soil. II. Their decomposition, Plant and Soil, 25, 313-328, 1966.

Iijima, A. and Tada, R.: Evolution of Tertiary sedimentary basins of Japan in reference to opening of the Japan Sea, J. Fac. Sci., Univ. Tokyo, Sec. II, 22, 121-171, 1990.

Jasper, J. P. and Hayes, J. M.: A carbon isotope record of $\mathrm{CO}_{2}$ levels during the late Quaternary, Nature, 347, 462-464, 1990. 
Jasper, J. P., Hayes, J. M., Mix, A. C., and Prahl, F. G.: Photosynthetic fractionation of ${ }^{13} \mathrm{C}$ and concentrations of dissolved $\mathrm{CO}_{2}$ in the central equatorial Pacific during the last 255,000 years, Paleoceanogr., 9, 781-798, 1994.

Kaplan, A., Schwartz, R., Lieman-Hurwitz, J., Ronen-Tarazi, M., and Reinhold, L.: Physiological and molecular studies on the responses of cyanobacteria to changes in the ambient inorganic carbon concentration, in: The Molecular Biology of Cyanobacteria, Kluwer Academic Publishers, Netherland, 469-485, 1993.

Karl, D., Letelier, R., Tupas, L., Dore, J., Christian, J., and Hebel, D.: The role of nitrogen fixation in biogeochemical cycling in the subtropical North Pacific Ocean, Nature, 386, 533-538, 1997.

Karuso, P., Bergquist, P. R., Buckleton, J. S., Cambie, R. C., Clark, G. R., and Rickard, C. E. F.: $13^{2}, 17^{3}$-cyclopheophorbide enol, the first porphyrin isolated from a sponge, Tetrahedron Lett., 27, 2177-2178, 1986.

Kashiyama, Y.: Reconstruction of biogeochemical environment of the past ocean based on compound-specific carbon and nitrogen isotopic compositions of sedimentary porphyrins, $\mathrm{Ph} . \mathrm{D}$. thesis, Graduate School of Science, The University of Tokyo, Japan, 2006.

Kashiyama, Y., Kitazato, H., and Ohkouchi, N.: An improved method for isolation and purification of sedimentary porphyrins by high-performance liquid chromatography for compoundspecific isotopic analysis, J. Chromatogr. A, 1138, 73-83, $2007 \mathrm{a}$.

Kashiyama, Y., Shiro, M., Tada, R., and Ohkouchi, N.: A novel vanadyl alkylporphyrins from geological samples: a possible derivative of divinylchlorophylls or bacteriochlorophyll- $a$ ? Chem. Lett., 36, 706-707, 2007b.

Kashiyama, Y., Ogawa, N. O., Kuroda, J., Shiro, M., Nomoto, S., Tada, R., Kitazato, H., and Ohkouchi, N.: Diazotrophic cyanobacteria as the major photoautotrophs during mid-Cretaceous oceanic anoxic events: nitrogen and carbon isotopic evidence from sedimentary porphyrin, Org. Geochem., 39, 532-549, 2008.

Keely, B. J., Brereton, R. G., and Maxwell, J. R.: Occurrence and significance of pyrochlorins in a lake sediment, Org. Geochem., 13, 801-805, 1988.

Keely, B. J., Harris, P. G., Popp, B. N., Hayes, J. M., Meischner, D., and Maxwell, J. R.: Porphyrin and chlorin distributions in a Lake Pliocene lacustrine sediment, Geochim. Cosmochim. Acta, 58, 3691-3701, 1994.

Keely, B. J. and Maxwell, J. R.: Structural characterization of the major chlorins in a Recent sediment, Org. Geochem., 17, 663669, 1991.

Keely, B. J., Prowse, W. G., and Maxwell, J. R.: The Treibs' hypothesis: An evaluation based on structural studies, Energy Fuels, 4, 628-634, 1990.

Kemp, A. E. S., Pearce, R. B., Koizumi, I., Pike, J., and Rance, S. $\mathrm{J} .:$ The role of mat-forming diatoms in formation of the Mediterranean sapropels, Nature, 398, 57-61, 1999.

Kennett, J. P.: Miocene and early Pliocene oxygen and carbon isotope stratigraphy of the southwest Pacific, Deep Sea Drilling Project, leg 90, Initial Rep. Deep Sea Drill. Proj., 90, 1383-1411, 1986.

Koizumi, I. and Matoba, Y.: On the top of the Nishikurosawa Stage, Mem. Geol. Soc. Japan, 32, 187-195, 1989 (in Japanese).

Kolber, Z. S., Plumley, F. G., Lang, A. S., Beatty, J. T., Blankenship, R. E., VanDover, C. L., Vetriani, C., Koblizek, M., Rathgeber, C., and Falkowski, P. G.: Contribution of aerobic photoheterotrophic bacteria to the carbon cycle in the ocean, Science, 292, 24922495, 2001.

Koshikawa, T.: The development of high-resolution, rapid, quantitative analytical method of sedimentary rocks by X-ray analytical microscope and application to interpretation of sedimentation mechanism of Miocene siliceous rocks. Ms.Sci. thesis, Graduate School of Science, The University of Tokyo, Japan, 2002 (in Japanese).

Kozono, M., Nomoto, S., and Shimoyama, A.: The first experimental simulation of thermal transformation of chlorophylls into benzoporphyrins in sediments, Chem. Lett., 2002, 470-471, 2002.

Kräutler, B., Jaun, B., Bortlik, K., Schellenberg, M., and Matile, P.: On the enigma of chlorophyll degradation: the constitution of a secoporphinoid catabolite, Angew. Chem. Int. Ed. Engl., 30, 1315-1318, 1991.

Kühl, M., Chen, M., Ralph, P. J., Schreiber, U., and Larkum, A. W. D.: A niche for cyanobacteria containing chlorophyll- $d$, Nature, 433, 8209, 2005.

Liu, K. -K. and Kaplan, I. R.: The eastern tropical Pacific as a source of ${ }^{15} \mathrm{~N}$-enriched nitrate in seawater off southern California, Limnol. Oceanogr., 34, 820-830, 1989.

Macko, S. A., Fogel, M. L., Hare, P. E., and Hoering, T. C.: Isotopic fractionation of nitrogen and carbon in the synthesis of amino acids by microorganism, Chem. Geol., 65, 79-92, 1987.

Martin, J. H., Coale, K. H., Johnson, K. S., Fitzwater, S. E., Gordon, R. M., Tanner, S. J., Hunter, C. N., Elrod, V. A., Nowicki, J. L., Coley, T. L., Barber, R. T., Lindley, S., Watson, A. J., Van Scoy, K., Law, C. S., Liddicoat, M. I., Ling, R., Stanton, T., Stockel, J., Collins, C., Anderson, A., Bidigare, R., Ondrusek, M., Latasa, M., Millero, F. J., Lee, K., Yao, W., Zhang, J. Z., Friederich, G., Sakamoto, C., Chavez, F., Buck, K., Kolber, Z., Greene, R., Falkowski, P., Chisholm, S. W., Hoge, F., Swift, R., Yungel, J., Turner, S., Nightingale, P., Hatton, A., Liss, P., and Tindale, N. W.: Testing the iron hypothesis in ecosystems of the equatorial Pacific Ocean, Nature, 371, 123-129, 1994.

Martinez, L., Silver, M. W., King, J. M., and Alldredge, A. L.: Nitrogen fixation by floating diatom mats: A source of new nitrogen to oligotrophic ocean waters, Science, 221, 152-154, 1983.

Matile, P., Hörtensteiner, S., Thomas, H., and Kräutler, B.: Chlorophyll breakdown in senescent leaves, Plant Physiol., 112, 14031409, 1996.

Meador, T. B. and Aluwihare, L. I.: Isotopic heterogeneity and cycling of organic nitrogen in the oligotrophic ocean, Limnol. Oceanogr., 52, 934-947, 2007.

Miller, S. R., Augustine, S., Le Olson, T., Blankenship, R. E., Selker, J., and Wood, A. M.: Discovery of a free-living chlorophyll- $d$-producing cyanobacterium with a hybrid proteobacterial/cyanobacterial small subunit rRNA gene, Proc. Natl. Acad. Sci. U. S. A., 102, 850-855, 2005.

Minagawa, M. and Wada, E.: Nitrogen isotope ratios of red tide organisms in the East China Sea: a characterization of biological nitrogen fixation, Mar. Chem., 19, 245-259, 1986.

Mino, Y., Saino, T., Suzuki, K., and Marañón, E.: Isotopic composition of suspended particulate nitrogen $\left(\delta^{15} \mathrm{~N}_{s u s}\right)$ in surface waters of the Atlantic Ocean from $50^{\circ} \mathrm{N}$ to $50^{\circ} \mathrm{S}$, Global Biogeochem. Cycles, 16, 1059, doi:10.1029/2001GB001635, 2003.

Miyashita, H., Ikemoto, H., Kurano, N., Adachi, K., Chihara, M., and Miyachi, S.: Chlorophyll- $d$ as a major pigment, Nature, 383, 
402-402, 1996.

Miyashita, H., Ikemoto, H., Kurano, N., Miyachi, S., and Chihara, M.: Acaryochloris marina gen. et sp. Nov. (cyanobacteria), an oxygenic photosynthetic prokaryote containing $\mathrm{Chl} d$ as a major pigment, J. Phycol., 39, 1247-1253, 2003.

Miyake, Y. and Wada, E., The abundance ratio of ${ }^{15} \mathrm{~N} /{ }^{14} \mathrm{~N}$ in marine environments, Rec. Oceanogr. Works Jpn., 9, 37-53, 1967.

Montoya, J. P., Carpenter, E. J., and Capone, D. G.: Nitrogen fixation and nitrogen isotope abundances in zooplankton of the oligotrophic North Atlantic, Limnol. Oceanogr., 47, 1617-1628, 2002.

Montoya, J. P., Holl, C. M., Zehr, J. P., Hansen, A., Villareal, T. A., and Capone, D. G.: High rates of $\mathrm{N}_{2}$ fixation by unicellular diazotrophs in the oligotrophic Pacific Ocean, Nature, 430, 1027-1031, 2004.

Mook, W. G., Bommerson, J. C., and Staberman, W. H.: Carbon isotope fractionation between dissolved bicarbonate and gaseous carbon dioxide, Earth. Planet. Sci. Lett., 22, 169-176, 1974.

Morel, F. M. M.: Zinc and carbon co-limitation of marinephytoplankton, Nature, 369, 740-742, 1994.

Nomaki, H., Heinz, P, Nakatsuka, T., Shimanaga, M., Ohkouchi, N., Ogawa, N. O., Kogure, K., Ikemoto, E., and Kitazato, H.: Different ingestion patterns of ${ }^{13} \mathrm{C}$-labeled bacteria and algae by deep-sea benthic foraminifera, Mar. Ecol. Prog. Ser., 310, 95108, 2006

Oberhuber, M., Berghold, J., Breuker, K., Hörtensteiner, S., and Kräutler, B.: Breakdown of chlorophyll: a nonenzymatic reaction accounts for the formation of the colorless "nonfluorescent" chlorophyll catabolites, Proc. Nat. Acad. Sci., 100, 6910-6915, 2003.

Ocampo, R., Bauder, C., Callot, H. J., and Albrecht, P.: Porphyrins from Messel oil shale (Eocene, Germany): structure elucidation, geochemical and biological significance, and distribution as a function of depth, Geochim. Cosmochim. Acta, 56, 745-761, 1992.

Ocampo, R., Callot, H. J., and Albrecht, P.: Occurrence of bacteriopetroporphyrins in oil shale, J. Chem. Soc., Chem. Commun., 1985, 200-201, 1985.

Ocampo, R., Callot, H. J., Albrecht, P., Popp, B. N., Horowitz, M. R., and Hayes, J. M.: Different isotope compositions of $\mathrm{C}_{32}$ DPEP and $\mathrm{C}_{32}$ etioporphyrin III in oil shale, Naturwiss., 76, 419-421, 1989.

Ocampo, R., Sachs, J. P., and Repeta, D. J.: Isolation and structure determination of a very unstable enol chlorin from sediments, 18th International Meeting on Organic Geochemistry, Maastricht, The Netherlands, 22-26 September, 1997.

Ocampo, R., Sachs, J. P., and Repeta, D. J.: Isolation and structure determination of the very unstable $13^{2}, 17^{3}$-cyclopheophorbide $a$ enol from recent sediments, Geochim. Cosmochim. Acta, 63, 3743-3749, 1999.

Ogawa, T. and Kaplan, A.: Inorganic carbon acquisition systems in cyanobacteria, Photosynth. Res., 77, 105-115, 2003.

Ohkouchi, N., Kashiyama, Y., Kuroda, J., Ogawa, N. O., Kitazato, H., An importance of cyanobacteria as a primary producer during Cretaceous Oceanic Anoxic Event 2, Biogeosciences, 3, 575605,2006 http://www.biogeosciences.net/3/575/2006/

Ohkouchi, N., Nakajima, Y., Ogawa, N. O., Chikaraishi, Y., Suga, H., Sakai, S., and Kitazato, H.: Carbon isotopic composi- tion of the tetrapyrrole nucleus in chloropigments from a saline meromictic lake: A mechanistic view for interpreting the isotopic signature of alkyl porphyrins in geological samples, Org. Geochem., 39, 510-520, 2008.

Ohkouchi, N., Nakajima, Y., Okada, H., Ogawa, N. O., Suga, H., Oguri, K., and Kitazato, H.: Biogeochemical processes in a meromictic lake Kaiike: Implications from carbon and nitrogen isotopic compositions of photosynthetic pigments, Environ. Microbiol., 7, 1009-1016, 2005.

Pagani, M., Freeman, K. H., and Arthur, M. A.: Late Miocene atmospheric $\mathrm{CO}_{2}$ concentrations and the expansion of $\mathrm{C}_{4}$ grasses, Science, 285, 876-879, 1999.

Pancost, R. D., Freeman, K. H., Wakeham, S. G., and Robertson, C. Y.: Controls on carbon isotope fractionation by diatoms in the Peru upwelling region, Geochim. Cosmochim. Acta, 61, 49834991, 1997.

Partensky, F., Hess, W. R., and Vaulot, D.: Prochlorococcus, a marine photosynthetic prokaryote of global significance, Microbiol. Mol. Biol. Rev., 63, 106-127, 1999.

Pennock, J. R., Velinski, D. J., Ludham, D. J., Sharp, J. H., and Fogel, M. L.: Isotope fractionation of ammonium and nitrate during the uptake by Skeletonema costatum: Implications for the $\delta^{15} \mathrm{~N}$ dynamics under bloom conditions, Limnol. Oceanogr., 41, 451459, 1996.

Prowse, W. G., Chicarelli, M. I., Keely, B. J., Kaur, S., and Maxwell, J. R.: Characterization of fossil porphyrins of the "diDPEP" type, Geochim. Cosmochim. Acta, 51, 2875-2877, 1987.

Prowse, W. G., Keely, B. J., and Maxwell, J. R.: A novel sedimentary metallochlorin, Org. Geochem., 16, 1059-1065, 1990.

Popp, B. N., Laws, E. A., Bidigare, R. R., Dore, J. E., Hanson, K. L., and Wakeham, S. G.: Effect of phytoplankton cell geometry on carbon isotopic fractionation, Geochim. Cosmochim. Acta, 62, 69-77, 1998.

Popp, B. N., Takigiku, R., Hayes, J. M., Louda, J. W., and Baker, E. W.: The post-Paleozoic chronology and mechanism of ${ }^{13} \mathrm{C}$ depletion in primary marine organic matter, Am. J. Sci., 289, 436-454, 1989.

Popp, B. N., Trull, T., Kenig, F., Wakeham, S. G., Rust, T. M., Tilbrook, B., Griffiths, F. B., Wright, S. W., Marchant, H. J., Bidigare, R. R., and Laws, E. A.: Controls on the carbon isotopic composition of Southern Ocean phytoplankton, Global Biogeochem. Cycles, 13, 827-844, 1999.

Postgate, J.: The origins of the unit of nitrogen fixation at the University of Sussex, Notes Rec. Royal Soc. Lond., 52, 355-362, 1998.

Rau, G. H., Sweeney, R. E., and Kaplan, I. R.: Plankton ${ }^{13} \mathrm{C} /{ }^{12} \mathrm{C}$ ratio changes with latitude: Differences between northern and southern oceans, Deep-Sea Res., 29, 1035-1039, 1982.

Raven, J. A.: Inorganic carbon acquisition by marine autotrophs, in: Advances in Botanical Research, 27, Academic Press, 85209, 1997.

Sachs, J. P. and Repeta, D.J.: Oligotrophy and nitrogen fixation during eastern Mediterranean sapropel events, Science, 286, 24852488, 1999.

Sachs, J. P., Repeta, D. J., and Goericke, R.: Nitrogen and carbon isotopic ratios of chlorophyll from marine phytoplankton, Geochim. Cosmochim. Acta, 63, 1431-1441, 1999.

Sakata, K., Yamamoto, K., Ishikawa, H., Yagi, A., Etoh, H., and Ina, K.: Chlorophyllone- $a$, a new phaeophorbide $a$ related compound 
isolated from Ruditapes phillippinarum as an antioxidative compound, Tetrahedron Lett., 31, 1165-1168, 1990.

Sanger, J. E.: Fossil Pigments in paleoecology and paleolimnology, Palaeogeogr. Palaeoclimatol. Palaeoecol., 62, 343-359, 1988.

Sampei, Y., Inaba, T., and Suzuki, N.: Abnormally abundant alkenone-derived $\mathrm{C}_{37}$ and $\mathrm{C}_{38}$ n-alkanes in Miocene Onnagawa siliceous mudstones, northeast Japan, Org. Geochem., 34, 12471258, 2003.

Scharek, R., Tupas, L. M., and Karl, D. M.: Diatom fluxes to the deep sea in the oligotrophic North Pacific gyre at Station ALOHA, Mar. Ecol. Prog. Ser., 182, 55-67, 1999.

Serebrennikova, O. V., Mozzhelina, T. K., and Shul'ga, A. M.: Structure and genesis of $\mathrm{C}_{30}$-homologues of petroleum vanadylporphyrins, Geokhimiya, 1987, 1494-1496, 1987 (in Russian).

Shaked, Y., Xu, Y., Leblanc, K., and Morel, F. M. M.: Zinc availability and alkaline phosphatase activity in Emiliania huxleyi: Implications for Zn-P co-limitation in the ocean, Limnol. Oceanogr., 51, 299-309, 2006.

Sharkey, T. and Berry, J. A.: Carbon isotope fractionation of algae as influenced by an inducible $\mathrm{CO}_{2}$ concentrating mechanism, in: Inorganic Carbon Uptake by Aquatic Photosynthetic Organisms, Am. Soc. Plant Physiol., Rockville, Maryland, 389-402, 1985.

Shul'ga, A. M., Serebrennikova, O. V., and Mozzhelina, T. K.: Research on PMR-spectra of $\mathrm{C}_{30}, \mathrm{C}_{31}$, and $\mathrm{C}_{32}$ homologues of petroleum porphyrins, Neftekhimiya, 26, 309-314, 1986 (in Russian).

Sigman, D. M., Altabet, M. A., McCorkle, D. C., Francois, R., and Fischer, G.: The $\delta^{15} \mathrm{~N}$ of nitrate in the Southern Ocean: Nitrogen cycling and circulation in the ocean interior, J. Geophys. Res., 105, 19599-19614, 2000.

Sigman, D. M., Granger, J., DiFiore, P. J., Lehmann, M. M., Ho, R., Cane, G., and van Geen, A.: Coupled nitrogen and oxygen isotope measurements of nitrate along the eastern North Pacific margin, Global Biogeochem. Cycles, 19, GB4022, doi:10.1029/2005GB002458, 2005.

Sigman, D. M., Robinson, R., Knapp, A. N., van Geen, A., McCorkle, D. C., Brandes, J. A., and Thunell, R. C.: Distinguishing between water column and sedimentary denitrification in the Santa Barbara Basin using the stable isotopes of nitrate, Geochem. Geophys. Geosyst., 4, 1040, doi:10.1029/2002GC000384, 2003.

Sundararaman, P. and Boreham, C. J.: Vanadyl 3-nor C 30 DPEP: indicator of depositional environment of a lacustrine sediment, Geochim. Cosmochim. Acta, 55, 389-395, 1991.

Sundararaman, P. and Boreham, C. J.: Comparison of nickel and vanadyl porphyrin distributions of sediments, Geochim. Cosmochim. Acta, 57, 1367-1377, 1993.

Sundararaman, P., Hwang, R. J., Ocampo, R., Boreham, C. J., Callot, H. J., and Albrecht, P.: Temporal changes in distribution of $\mathrm{C}_{33}$ cycloheptenoDPEP and 17-nor $\mathrm{C}_{30}$ DPEP in rocks, Org. Geochem., 21, 1051-1058, 1994.

Suzuki, N., Sampei, Y., and Koga, O.: Norcholestane in Miocene Onnagawa siliceous sediments, Japan, Geochim. Cosmochim. Acta, 57, 4539-4545, 1993.

Tabita, F. R.: Biochemistry and molecular regulation of carbon dioxide metabolism in cyanobacteria, in: The Molecular Biology of Cyanobacteria, Kluwer Academic Publishers, Netherland, 437-467, 1993.

Tada, R.: Origin of rhythmical bedding in middle Miocene siliceous rocks of the Onnagawa Formation, northeastern Japan, J. Sed. Petrol., 61, 1123-1145, 1991.

Taylor, F. J. R.: Symbioses in marine microplankton, Ann. Inst. Oceanogr. Paris, 58, 61-90, 1982.

Thingstad, T. F. and Rassoulzadegan, F.: Nutrient limitations, microbial food webs and 'biological pumps': suggested interactions in a P-limited Mediterranean, Mar. Ecol.-Prog. Ser., 117, 299306, 1995.

Thode, H. G., Shima, M., Rees, C. E., and Krishnamurthy. K. V.: Carbon-13 isotope effects in systems containing carbon dioxide, bicarbonate, carbonate, and metal ions, Canadian J. Chem., 43, 582-589, 1965.

Ting, C. S., Rocap, G., King, J., Chisholm, S. W., 2002. Cyanobacterial photosynthesis in the oceans: the origins and significance of divergent light-harvesting strategies. Trends Microbiol. 10, 134-142.

Treibs, A.: Chlorophyll and hemin derivatives in organic materials, Angew. Chem., 49, 682-686, 1936.

Tyrrell, T.: The relative influences of nitrogen and phosphorus on oceanic primary production, Nature, 400, 525-531, 1999.

Uemura, F. and Sawamura, K.: Notes on diatomaceous carbonate nodule in the Neogene Tertiary System, of Ajigasawa area, Aomori Prefecture, Bull. Geol. Survey Japan, 24, 185-191, 1973 (in Japanese).

Venrick, E. L.: The distribution and significance of Richelia intracellularis Schmidt in the North Pacific Central Gyre, Limnol. Oceanogr., 19, 437-445, 1974.

Verne-Mismer, J., Ocampo, R., Bauder, H. J., Callot, H. J., and Albrecht, P.: Structural comparison of nickel, vanadyl, copper, and free base porphyrins from Oulad Abdoun oil shale (Maastrichtian, Morocco), Energy Fuels, 4, 639-643, 1990.

Verne-Mismer, J., Ocampo, R., Callot, H. J., and Albrecht, P. Molecular fossils of chlorophyll- $c$ of the 17-nor-DPEP series. Structure determination, synthesis, geochemical significance, Tetrahedron Lett., 29, 371-374, 1988.

Villareal, T. A.: Marine nitrogen-fixing diatom-cyanobacteria symbioses, in: Marine Pelagic Cyanobacteria: Trichodesmium and Other Diazotrophs, Kluwer Academic Publishers, Dordrecht, 163-174, 1992.

Voss, M., Dippner, J. W., and Montoya, J. P.: Nitrogen isotope patterns in the oxygen-deficient waters of the eastern tropical North Pacific Ocean, Deep Sea Res., Part I 48, 1905-1921., 2001.

Wada, E.: Nitrogen isotope fractionation and its significance in biogeochemical processes occurring in marine environments, in: Isotope Marine Chemistry, Uchida Rokkakudo, Tokyo, 375-398, 1980.

Wada, E. and Hattori, A.: Nitrogen in the Sea: Forms, Abundances, and Rate Processes, CRC Press, Boca Raton, 1991.

Walker, J. S., Keely, B. J.: Distribution and significance of chlorophyll derivatives and oxidation products during the spring phytoplankton bloom in the Celtic Sea April 2002, Org. Chem., 35, 1289-1298, 2004.

Waser, N. A. D., Harrison, P. J., Nielsen, B., Calvert, S. E.: Nitrogen isotope fractionation during the uptake and assimilation of nitrate, nitrite, ammonium, and urea by a marine diatom, Limnol. Oceanogr., 43, 215-224, 1998a.

Waser, N. A., Yin, K. D., Yu, Z. M., Tada, K., Harrison, P. J., Turpin, D. H., Calvert, S. E.: Nitrogen isotope fractionation during nitrate, ammonium and urea uptake by marine diatoms and 
coccolithophores under various conditions of $\mathrm{N}$ availability, Mar. Ecol.-Prog. Ser., 169, 29-41, 1998b.

White, A. E., Prahl, F. G., Letelier, R. M., and Popp, B. N.: Summer surface waters in the Gulf of California: Prime habitat for biological $\mathrm{N}_{2}$ fixation, Global Biogeochem. Cycles, 21, GB2017, doi:10.1029/2006GB002779, 2007.

Woodruff, F. and Savin, S. M.: Miocene deepwater oceanography, Paleoceanogr., 4, 87-140, 1989.

Woodruff, F. and Savin, S.M.: Mid-Miocene isotope stratigraphy in the deep sea: high-resolution correlations, paleoclimatic cycles, and sediment preservation, Paleoceanogr., 6, 755-806, 1991.

Yamamoto, K., Sakata, K., Watanabe, N., Yagi, A., Brinen, L. S., and Clardy, J.: Chlorophyllonic acid a methyl ester, a new chlorophyll- $a$ related compound isolated as an antioxidant from Short-Necked Clam, Ruditapes philippinarum, Tetrahedron Lett., 18, 2587-2588, 1992.
Yamamoto, M., Naraoka, H., Ishiwatari, R., and Ogihara, S.: Carbon isotope signatures of bacterial 28-norhopanoic acids in Miocene-Pliocene diatomaceous and phosphatic sediments, Chem. Geol., 218, 117-133, 2005.

Yamamoto, M. and Watanabe, Y.: Biomarker geochemistry and paleoceanography of Miocene Onnagawa diatomaceous sediments, northern Honshu, Japan, in: Proc. 29th Int'l. Geol. Congr. Part C: Siliceous, Phosphatic and Glauconitic Sediments of the Tertiary and Mesozoic, VSP, Utrecht, 53-74, 1994.

York, J. K., Tomasky, G., Valiela, I., and Repeta, D. J.: Stable isotopic detection of ammonium and nitrate assimilation by phytoplankton in the Waquoit Bay estuarine system, Limnol. Oceanogr., 52, 144-155, 2007.

Zehr, J., Waterbury, J., Turner, P., Montoya, J., Omoregie, E., Steward, G., Hansen, A., and Karl, D.: Unicellular cyanobacteria fix $\mathrm{N}_{2}$ in the subtropical North Pacific Ocean, Nature, 412, 635-638, 2001 . 